\title{
RESEARCH
}

\section{"BÁNH TRÔI NƯỚC" AND THREE ENGLISH VERSIONS OF TRANSLATION: A SYSTEMIC FUNCTIONAL COMPARISON}

\author{
Hoang Van Van* \\ Center of Foreign Language Education Research, Linguistics and International Studies, \\ VNU University of Languages and International Studies, Pham Van Dong, Cau Giay, Hanoi, Vietnam
}

Received 20 June 2018

Revised 27 July 2018; Accepted 30 July 2018

\begin{abstract}
This paper is concerned with a comparison of the three English versions of translation: "The Floating Cake" translated by John Balaban, "The Cake That Drifts In Water" translated by Huỳnh Sanh Thông and "Floating Sweet Dumpling" translated by Marilyn Chin with the source poem "Bánh trôi nước" by the Vietnamese renowned poetess Hồ Xuân Hương. The theoretical framework employed for analysis and comparison of the texts is systemic functional linguistics. The results show that there are both similarities and differences between the translated versions and the source poem, and between the translated versions in terms of ideational, interpersonal and textual meanings. The results also indicate that there are more differences in lexical choice (the choice of words and groups/phrases) than in syntactic choice (the choice of transitivity, mood, and thematic patterns) between the three translated versions and the original poem, and between the three translated versions.
\end{abstract}

Keywords: systemic functional linguistics, context, text, ideational metafunction, interpersonal metafunction, textual metafunction, source poem, translated versions

\section{Introduction}

In this paper, an attempt is made to compare three English versions of translation: "The Floating Cake" translated by John Balaban, "The Cake That Drifts In Water" translated by Huynh Sanh Thong, and "Floating Sweet Dumpling" by translated by Marilyn Chin with the Vietnamese source poem "Bánh trôi nước" written by Hồ Xuân Hương. The theoretical framework employed for analysis and comparison of the texts is systemic functional linguistics. There are various reasons for choosing this topic, but four seem to be prominent. First,

\footnotetext{
* Tel.: 84-946296999
}

Email:vanhv.sdh@gmail.com both the source poem and the translated versions are short (each consists of five lines including the title). Secondly, the source poem is written by Hồ Xuân Hương - one of the most popular poets in Vietnam who is so renowned for her poetic skills that she is considered by the Vietnamese "bà chúa thơ Nôm" (the Princess of Vietnamese folk poetry). Thirdly, the poem is translated into English by three famous translators: John Balaban, an American poet, who is "twice a National Book Award finalist for his own poetry and is one of the preeminent American authorities on Vietnamese literature" (https://www.amazon.com/Spring-EssencePoetry-Xu\%C3\%A2n-Huong/dp/1556591489), Huỳnh Sanh Thông, a Vietnamese-born American Yale scholar who is famous for his 
translation of Truyện Kiều (The Tale of Kieu) from Vietnamese into English, and Marilyn Chin, also a famous American poetess. And fourthly, the source poem is written in a folk style; it is not difficult to uncover its meaning through linguistic analysis. So the choice of this topic is perfect for "comparing the various translations done of the same original text by different translators into a single TL (target language) in order to systematize and objectify the teaching of translation" (Wilss, 1982: 28). The paper will fall into five parts. Following Part 1 - Introduction, Part 2 states the aim of the study and raises research questions for the study. Part 3 provides an overview of systemic functional linguistics, paying particular attention to those concepts of the model that are relevant to the analysis and comparison of the translated versions and the source poem. Part 4 deals with the design and methodology of the study in which I will present data collection, data analysis, and discuss and compare the results obtained from the analysis to establish the similarities and differences between the three translated versions and "Bánh trôi nước", and between the three translated versions. Finally, Part 5 Conclusion - summarizes the main points of the study, points out limitations of the study, and makes suggestions for further research.

\section{Aim of the study and research questions}

As stated, the overarching aim of this study is to make a comparison between the three English versions of translation and the original poem "Bánh trôi nước", and between the three translated versions to establish the similarities and differences between them. To fulfil this aim, two questions are raised for exploration:

1. How are the source poem and the translated versions constructed in terms of ideational, interpersonal, and textual meanings?

2. To what extent are the translated versions similar to and different from the source poem and to what extent are the translated versions similar to and different from one another in terms of ideational, interpersonal and textual meanings?

\section{The theoretical framework}

The theoretical framework adopted in this study is systemic functional linguistics (SFL). SFL is a model of language in context. It was originally developed by Halliday in the early 1960s. Since then the model has constantly evolved toward perfection and has been used as the theoretical framework for a great number of works in language description, discourse analysis, text generation, translation studies, dictionary compilation, etc. Accounts of the SF framework are now widely available in works by Halliday (1973, 1978, 1992, 1996), Matthiessen (1995), Halliday \& Martin (1993), Halliday \& Hasan (1985), Halliday \& Matthiessen (1999), Matthiessen \& Bateman (1991), Martin (1992), Burns (1990), Eggins (2004), Hoang (2001a, 2001b, 2005, 2012), Schleppegrell (2008), Hasan (2011), Hasan \& Perrett (1994), Thompson (2004), Webster (2015), and many others. For the purpose of their study, however, each scholar approaches the model from a different perspective. As this paper is about a comparison of texts (a source poem and its three English versions of translation), I will try to be selective, relating my review of the SF model to those contents that appear to be relevant to its concern. To make the task manageable, I will begin by examining the notion of text. Then I will discuss the relationship between social context and functional organization of language. The review will end with a brief description of three strands of meaning (metafunctions) and their respective lexicogrammatical realizations as postulated in the SF model. 


\subsection{What is a text?}

There are many ways to define a text/ discourse (see Brown \& Yule, 1983; Cook, 1989; Nunan, 1993; McCarthy, 2000; Hoang, 2005; Crystal, 2008; and many others), but in this paper, the definition by Halliday and Hasan will be adopted. In two of their seminal and most-cited books entitled Cohesion in English published by Longman in 1976 and Language, Context, and Text: Aspects of Language in Social-semiotic Perspective pubished by Deakin University Press in 1985, Halliday and Hasan conceptualize text as "any passage, spoken or written, of whatever length, that does form a unified whole" (1976: 1); it is "language that is functional" - "language that is doing some job in some context" (1985: 10). They emphasize that a text is essentially a semantic unit (1985: 10) - a unit of language in use (1976: 1). It is not a grammatical unit, like a clause or a sentence (1976: 1), not something that can be defined as being just another kind of sentence, only bigger (1985: 10). Halliday \& Hasan (1985: 10) further state that a text is both an object in its own right (it may be a highly valued object, for example something that is recognized as a great poem) and an instance of social meaning in a particular context of situation. "It is an instance of the process and product of social meaning in a particular context of situation" (1985: 11). They suggest that there is a close relation between the text and the social context and that "If we treat both text and context as semiotic phenomena, as 'modes of meaning', we can get from one to the other in a revealing way" (1985: 11-2).

\subsection{The relationship between social context} and functional organization of language

Halliday (1991: 8) provides the best model for interpreting the relationship between the social context and the functional organization of language which is reproduced in Figure 1 below:

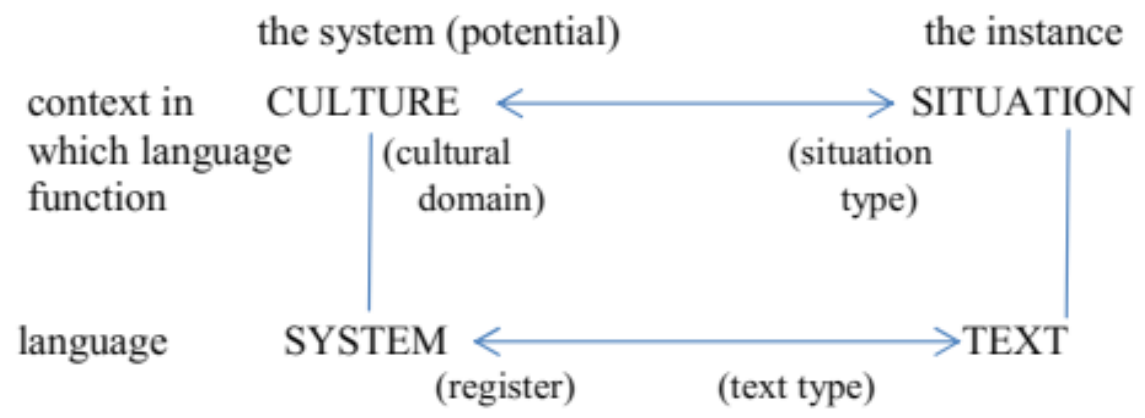

Figure 1. The relation between language and social context

* Notes: left - right: instantiation, top - bottom: realization

As Figure 1 shows, Halliday's model consists of four constructs: (context of) CULTURE, (context of) SITUATION, (language) SYSTEM, and TEXT. According to Halliday (Ibid.), the context of culture is the context for meaning potential (for language as system), and the context of situation is the context for the particular instances (for language as text). Halliday suggests that the relationship between context of culture and context of situation and that between language and text are that of instantiation: (context of) situation instantiates (context of) culture and text instantiates language. By contrast, the relationship between context of culture and language and that between context of situation 
and text is that of realization: language realizes context of culture and text realizes context of situation. As this study is concerned mainly with the analysis and comparison of texts, it is useful to explore in some more detail the relationship between text and context of situation - the immediate environment in which the texts under study function.

It can be noted that although Figure 1 shows us the general realizational relationship between text and context of situation, it does not tell us "how to characterize a text in its relation to its social context"; neither does it show us "how to get from the context of situation to the text" (Halliday \& Hasan, 1985: 12). To solve these problems, Halliday \& Hasan (1985: 38) suggest we need to develop and incorporate into the general theory of SFL a "concept of a variety of languages, corresponding to a variety of situations". The concept they propose is REGISTER - a conceptual framework of three headings: field of discourse, tenor of discourse, and mode of discourse. Halliday \& Hasan then characterize these register dimensions as follows:

1. The field of discourse refers to what is happening, to the nature of the social action that is taking place: what is it that the participants are engaged in, in which the language figures as some essential components?

2. The tenor of discourse refers to who is taking part, to the nature of the participants, their statuses and roles: what kinds of role relationship obtain among the participants, including permanent and temporary relationships of one kind or another, both the types of speech role that they are taking on in the dialogue and the whole cluster of socially significant relationships in which they are involved?
3. The mode of discourse refers to what the language is playing, what it is that the participants are expecting the language to do for them in that situation: the symbolic organization of the text, the status that it has, and its function in the context, including the channel (is it spoken or written or some combination of the two?) and also the rhetorical mode, what is being achieved by the text in terms of such categories as persuasive, expository, didactic, and the like.

(Halliday \& Hassan, 1985: 12)

\subsection{Three strands of meaning and their lexicogrammatical realizations}

Metafunction is a fundamental principle of language (Hoang, 2013). At the contextual level, the register (the context of situation) of a text can be analyzed in terms of the field of discourse, the tenor of discourse and the mode of discourse. At the linguistic level, a text can be analyzed respectively in terms of three metafunctions or strands of meaning realized through three respective lexicogrammatical structures: the ideational metafunction which comprises the experiential metafunction realized through the transitivity system and the logical metafunction realized through the expansion and projection systems, the interpersonal metafunction realized through the mood system, and the textual metafunction realized through the theme system. For analysis of the internal structure of the elements below the clause, some groups and phrases are also re-examined in this review.

\subsubsection{The experiential metafunction and its realization through the transitivity system}

The ideational metafunction is a general social function of language that we use to construe/represent reality in the linguistic system. It is a function of language 
that expresses the 'reflective' as well as 'experiential' aspect of meaning through the system of transitivity. Transitivity refers to the different process (clause) types. Basically, there are three components in the process that provide the frame of reference of what goes on (Halliday, 1985: 101, 1994: 107). These are: the process itself, the participants in the process and the circumstances associated with the process. There are three main types of process: material, mental, and relational. In addition to these, there are three subtypes of process: behavioural, verbal, and existential.

Material process is the process of doing: action and event such as kicking, striking, running, walking. Related to the process itself, there may be one, two or even three participants. When a material process has one participant this role is referred to as Actor (one that does the deed) as in He (Actor) was coming (Process: material); when it has two participants, these roles are referred to respectively as Actor and Goal (one that is affected by the action) as in I (Actor) shot (Process: material) an arrow (Goal) into the air (Circumstance) (from "I Shot an Arrow into the Air" by Longfellow); and when it has three participants, these roles are referred to respectively as Actor, Goal and Receiver (one that benefits from the process) as in $\mathrm{He}$ (Actor) gave (Process: material) a book (Goal) to her (Receiver). In terms of voice, like all other process types in the transitivity system, a material process can come in either the middle voice as in The boy came in or the effective voice as in The boy kicked the ball; it can also come in either the active voice as in The boy kicked the ball or the passive voice as in The ball was kicked by the boy.

Behavioural process is the process of physiological and psychological behaviour such as breathing, crying, drinking. Typical of this type of process is that there is usually one participant referred to as Behaver (one who behaves) as in She (Behaver) cried (Process: Behavioural) softly (Circumstance), and this participant is always a conscious being, not a lifeless thing; e.g. He laughed but not The tree laughed, The dog barked but not The door barked, etc. However, when a behavioural process has two participants, these roles are referred to respectively as Behaver and Range (one that specifies the scope of the behavioural process) or Phenomenon (one that is behaved) as in I (Behaver) breathed (Process: behavioural) a song (Range/Phenomenon) into the air (Circumstance) (from "I Shot an Arrow into the Air" by Longfellow).

Mental process is the process of sensing such as thinking, loving, wanting, hoping. It consists of four main subtypes: cognitive (thinking, knowing, realising), perceptive (hearing, sensing, feeling), affective (loving, hating, adoring, pampering), and desiderative (wanting, desiring, wishing). In a mental process, there are usually two participants referred to respectively as Senser (one who senses, feels, thinks, or wants) and Phenomenon (one that is sensed, felt, thought of, or wanted) as in The boy (Senser) loved (Process: mental) the girl (Phenomenon), and $I$ in $I$ (Senser) heard (Process: mental) a noise (Phenomenon) from outside (Circumstance). Like the Behaver in a behavioural process, the Senser in a mental process is always a human being.

Verbal process is the process of saying such as saying, telling, speaking, talking. This type of process covers not only verbs of saying but any kind of symbolic exchange such as showing, indicating. Unlike behavioural and mental process, a verbal process may not require a conscious participant and it can contain one participant referred to as Sayer (one that puts out a signal) as in $\mathrm{He}$ (Sayer) 
said (Process: saying) loudly (Circumstance); two participants referred to respectively, depending on each particular subtype of verbal process, as Sayer and Target (one that the verbalisation is directed to) as in They (Sayer) told (Process: verbal) me (Target) so (Circumstance), and Sayer and Verbiage (the name of the verbalisation itself) as in He (Sayer) ordered (Process: verbal) two beers (Verbiage); and even three participants referred to respectively as Sayer, Target and Recipient (one that benefits from the verbal process) as in She (Sayer) spoke (Process: verbal) French (Target) to me (Recipient).

Relational process is the processes of being, having, and being at. It comes under three subtypes: (i) the intensive as in She's good and She's the teacher in charge; (ii) the circumstantial as in She is in the room; and (iii) the possessive as in She has a beautiful voice. Like other process types which have the middle and effective voice, relational process comes under two modes: attributive (middle voice) and identifying (effective voice). When a relational process is in the attributive mode, it has one participant referred to as Carrier and the quality or the thing showing that the Carrier belongs to a class of things which is referred to as Attribute as in She (Carrier) is (Process: relational) good (Attribute), My life (Carrier) is (Process: relational) like a red red rose (Attribute). The Carrier is realised by a nominal group and the Attribute is realised by an adjective or an indefinite nominal group. When a relational clause is in the identifying mode, it has two equating participants, one identifying the other, which are referred to respectively in two pairs of terms as Identified/Identifier and Token/Value; e.g. He (Identified/Token) is (Process: relational) the best doctor (Identifier/Value). Intensive process is the process which expresses being in terms of " $\mathrm{x}$ is a' as in She is the teacher and ' $\mathrm{x}$ is an instance of a' as in She is a teacher. Circumstantial process is the process which expresses being in terms of circumstantial elements such as time, place, distance, reason. The relation between the participant and its circumstantial element is that of Carrier and Attribute. Possessive process expresses being in terms of ownership, the relation between the two terms can be characterised as Possessor and Possessed but for generalisation and convenience, they are referred to as Carrier and Attribute; e.g. He (Carrier/Possessor) had (Process: relational) a big car (Attribute/ Possessed).

Existential process is the process of existing, indicating that something or some natural force exists. In this type of process, there is generally a participant, the Existent and one or two circumstantial elements; e.g. There is (Process: existential) a man (Existent) in the room (Circumstance). (For details of process types in English, see Halliday, 1985, 1994; Halliday \& Matthiessen, 2004; and for details of process types in Vietnamese, see Hoang 2005, 2012; Diep, 2005).

\subsubsection{The logical metafunction and its} realization through the systems of expansion and projection

In everyday communication, the speaker is less likely to focus on construing things or events as single, isolated phenomena. On the contrary, s/he often uses the infinite resources of language to form complex categories such as Leave a kiss within the cup, and I'll not ask for wine (from "To Celia" by Ben Jonson, cited in Halliday \& Hasan, 1985: 18), in which two single states of affair Leave a kiss within the cup and I will not ask for wine are combined to form a clause complex having a logico-semantic or rhetorical pattern of If $x \ldots$ then $y$. Clause 
complex, according to Halliday (1985, 1994), Halliday \& Hasan (1985), and Halliday \& Matthiessen (2004), is the resource for forming two general systems: (1) taxis and logicosemantic relation. Taxis is concerned with degrees of interdependency. It has two delicate systems each of which indicates a kind of logical relation between clauses: paratactic relation and hypotactic relation. When two clauses in a complex are of equal status, they are said to be in paratactic relation. In contrast, when two clauses in a complex are of unequal status, they are said to be in hypotactic relation. In systemic functional grammar, logico-semantic relation comprises two fundamental relationships: expansion and projection. Expansion refers to a complex in which the secondary clause expands the primary clause by means of (i) elaboration: "one clause elaborates on the meaning of another by specifying or describing it" (Halliday \& Matthiessen, 2004: 396) (e.g. My watch stops; it's broken down), (ii) extension: "one clause extends of the meaning of another by adding something new to it" (Halliday \& Matthiessen, 2004: 405) (e.g. Winter has gone, and spring has come), and (iii) enhancement: "one clause [or subcomplex] enhances the meaning of another by qualifying it in one of a number of possible ways: by reference to time, place, manner, cause or condition" (Halliday \& Matthiessen, 2004: 410) (e.g. When he came, she had gone). Projection refers to a complex in which the secondary clause is projected through the primary clause which instates it as a locution or an idea. Related to locution and ideas are two logico-semantic relations referred to respectively as quoting and reporting. Quoting refers to a complex in which one clause projects another clause and the projected clause represents that which is said (e.g. He said: "She's coming."), and the projected clause(s) and the projecting clause are of equal status. In contrast, reporting refers to a complex in which one clause projects another clause and the projected clause represents the idea of that which is said/thought, and the projected clause and the projecting clause are of unequal status (e.g. He said that she was coming). (For more details of clause complexing, see Halliday, 1994, Chapter 7; Halliday \& Matthiessen, 2004, Chapter 7; Hasan, 1993; Hoang, 2012, 2013).

\subsubsection{The interpersonal metafunction and its realization through the mood system}

The interpersonal metafunction is another general social function that we use language to enact roles and relations between speaker and addressee as meaning (Matthiessen et al., 2010: 128; Martin \& Rose, 2013: 7). According to Halliday (1985, 1994) and Halliday \& Matthiessen (2004), when a speaker interacts with others to exchange information or to influence their behaviour and get things done, he adopts for himself a certain role such as 'questioner' and, in so doing, assigns a complementary role, such as 'informant', to his addressee. Unless the conversation is very one-sided, the roles of 'questioner' and 'informant' tend to alternate between the interlocutors engaged in a conversation. Halliday (1994) provides a table to characterise the primary speech roles which can be represented in Figure 2 below.

\begin{tabular}{|c|c|c|}
\hline $\begin{array}{c}\text { Commodity } \\
\text { exchange }\end{array}$ & $\begin{array}{c}\text { (a) } \\
\text { goods-\&- } \\
\text { services } \\
\text { exchange }\end{array}$ & $\begin{array}{c}\text { (b) } \\
\text { information }\end{array}$ \\
\hline (i) giving & $\begin{array}{c}\text { Would you like } \\
\text { this teapot? }\end{array}$ & $\begin{array}{c}\text { 'offer's giving her } \\
\text { the teapot }\end{array}$ \\
\hline (ii) & $\begin{array}{c}\text { 'command' } \\
\text { Give me that } \\
\text { teapot! }\end{array}$ & $\begin{array}{c}\text { 'question' } \\
\text { Is she giving me } \\
\text { the teapot? }\end{array}$ \\
\hline
\end{tabular}

Figure 2. Primary speech roles (Halliday, 1994: 69) 
As Figure 2 shows, all the roles are traced back to a form of either giving or demanding. These roles are simultaneously related to the two general categories of commodity negotiated between people: goods- $\&$-services or information. When speech roles interact with types of commodity they produce four general speech roles: giving goods- $\&$-services $=$ offer, giving information $=$ statement, demanding goods- $\&$-services $=$ command, and demanding information $=$ question. Giving goods-\&-services can be realised either by a declarative clause as in He's giving her the teapot or by an interrogative clause as in Would you like this teapot?; giving information is typically realised by a declarative clause as in e.g. He's giving her the teapot; demanding goods-\&-services is typically realised by an imperative clause as in Give me that teapot!; and demanding information is typically realised by an interrogative clause as in Is she giving me the teapot? Figure 3 below represents a fragment of the mood system in English.

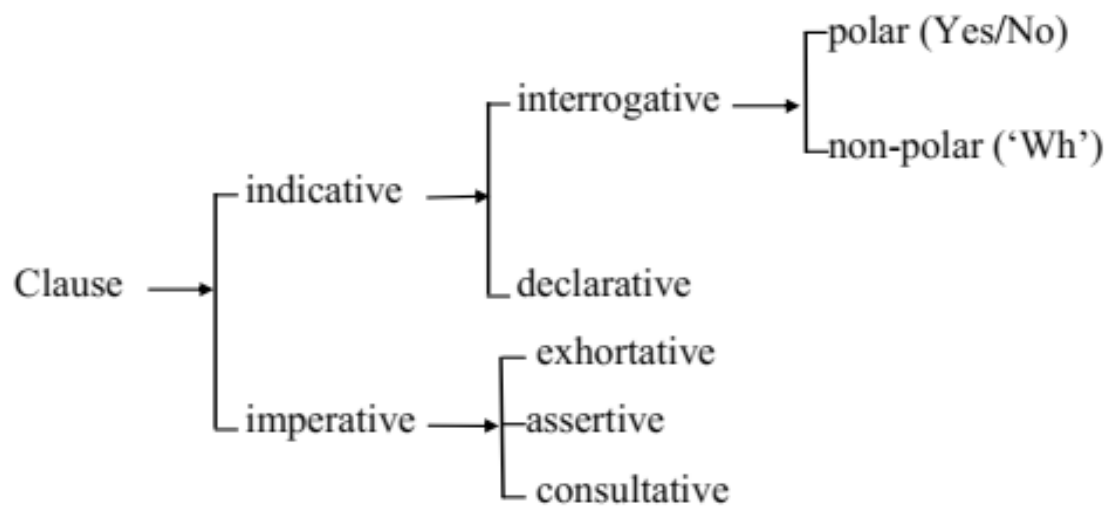

Figure 3. A fragment of the English MOOD system

Figure 3 shows that in the mood system, there are two choices: 'indicative' and 'imperative'. If 'indicative' is chosen, it will allow two more choices: 'interrogative' as in Is Bánh trôi nước a lyric? and 'declarative' as in Bánh trôi nước is a lyric; and between 'interrogative' and 'declarative', if 'interrogative' is chosen, it will open for two more delicate choices: 'polar' (requiring the answer "Yes/No") as in Is Bánh trôi nước a lyric? and 'non-polar' (requiring the answer to the missing information) as in What kind of poem is Bánh trôi nước? In contrast, if 'imperative' is chosen, it will allow three delicate choices: 'exhortative' as in Read the poem, 'assertive' as in You have to read the poem, and 'consultative' as in Can you read the poem?
As an exchange or interactive event, an English clause can be seen as consisting of two components: Mood (M) and Residue (Res). The Mood is the component whose function in the clause is to carry the syntactic burden of the exchange and to carry the argument forward. In English, the Mood component consists of two functional elements: Subject (Subj) and Finite (Fin). The Subject is the nominal component of the Mood; it is the thing by reference to which a proposition can be affirmed or denied. The Finite is the verbal element in the Mood which has the function of making the proposition finite; that is to say, it brings the proposition down to earth so that something can be argued about. The Residue is the remainder of the clause. It consists of 
three functional components: (i) Predicator (Pred), (ii) Complement (Compl), and (iii) Adjunct (Adjct). The Predicator is present in all non-elliptical major clauses. It is realised by a verbal group; the Complement is an element within the Residue which has the potential of being Subject, and like the Subject it is typically realised by a nominal group; and the Adjunct is the element also within the Residue which is typically realised by an adverbial group or a prepositional phrase. Below is an example of the functions of these elements in the interpersonal clause in English:

\begin{tabular}{|l|l|l|l|l|}
\hline She & is & reading & a book & in the library \\
\hline Mood & Residue \\
\hline Subject & Finite & Predicator & Complement & Adjunct \\
\hline
\end{tabular}

Mood is concerned with polarity which can be positive (yes) or negative (no). Between positive and negative polarity, there lies an area of meaning referred to in systemic functional grammar as modality. Modality as an interpersonal subsystem has two main choices (types): modalization and modulation. Modalization (epistemic modality in traditional semantics) is concerned with some degree of probability as can in She can be a poetess and usuality as always in He always changed his mind. In contrast, modulation (deontic modality in traditional semantics) is concerned with some degree of obligation as should in He should tell her and inclination as won't in They won't go. (For details of mood and modality in the English interpersonal clause, see Halliday, 1985, 1994, 2012; Halliday \& Matthiessen, 2004; Matthiessen et al, 2010; Martin \& Rose, 2013; and for details of mood and modality in the Vietnamese interpersonal clause, see Thai, 2004; Diep, 2005; Hoang, 2009). Figure 4 represents the basic choices of the modality system.

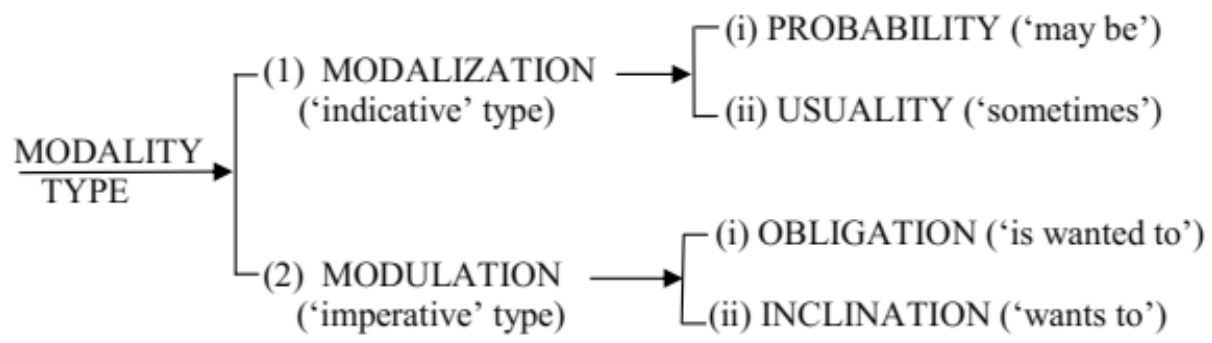

Figure 4. System of modality: basic types (Halliday \& Matthiessen, 2004: 618)

3.3.4. The textual metafunction and its realization through the theme system

The textual metafunction is the third strand of meaning that we use "to organize our enactments and representation as meaningful text" (Martin \& Rose, 2013: 7). It is concerned with creating relevance between parts of what is being said and between the text and the context of situation. It is expressed through the system of theme. Relevant to the realization of the system of theme are two functional elements: Theme (Th) and Rheme (Rh). The Theme serves as the point of departure of the message, which coincides with the initial element(s) of the clause; and the Rheme is the remainder of the message. By analysing the thematic structure of the clauses 
in a text we can find out the text's mode of development: how a topic is developed in the text and in what ways different parts of the text are related to each other semantically and logically. Theme may be realised by a nominal group, a prepositional phrase, an adverbial group, or even a clause in the case of predicated theme in English. In terms of structure, Theme may be single or multiple; in terms of meaning Theme may be marked or unmarked; and in terms of function, Theme may be topical, interpersonal or textual. A Theme is single when the thematic element itself is represented by just one constituent - a nominal group, an adverbial group, or a prepositional phrase. In contrast, a Theme is multiple when it has a further internal structure of its own. Here we distinguish between topical Theme, interpersonal Theme and textual Theme. A topical Theme is one that is conflated with an experiential element of the clause: it can be Actor/Agent, Goal/ Medium or Circumstance. An interpersonal Theme represents the interpersonal element with which the speaker or writer acts on the listener or reader. An interpersonal Theme may contain (i) a modal Theme which consists of a modal adjunct, the definite element in the case of yes/no interrogative clauses, and (iii) a vocative element. And a textual Theme represents the meaning that is relevant to the context: both the preceding and the following text (co-text) and the context of situation. It may have any combination of three textual elements: (i) a continuative element; e.g., yes, no, well; (ii) a structural element, e.g., and, but; and (iii) a conjunctive element, e.g., also, although. An unmarked Theme is one that is usual or typical, whereas a marked Theme is one that is unusual. In the declarative clause, an unmarked Theme is one that conflates with the Subject, while a marked Theme is a constituent functioning as some element of the rest of the interpersonal clause, including Predicator, Complement, and Adjunct.

Another aspect of the textual meaning has to do with what Halliday $(1985,1994,2012)$ and Halliday \& Matthiessen (2004) refer to as the Given and New information. To illustrate these two textual functions, let us consider the clause taken from the poem Ozymandias by the British poet Percy Bysshe Shelley I met a traveller from an antique land (cited in Hayakawa, 1959: 157). From the point of view of traditional grammar, this clause has a standard word-order of Subject $(I)+$ Verb $(m e t)+$ Object (a traveller from an antique land) (SVO). However, there are numerous other ways in which the semantic content of the clause can be realised. For example:

A traveller from an antique land was met by me. It was me who met a traveller from an antique land. It was a traveller from an antique land that I met.

Who I met was a traveller from an antique land.

Which of these options is actually selected by the writer/speaker will depend on the context in which the utterance occurs and the status of information within the discourse. One important consideration is whether the information has already been introduced into the discourse or is assumed to be known to the reader/listener. Such information is referred to as Given information (G). In contrast with information which is given, there is what Halliday calls New information (N) - information which is introduced for the first time. It is important to bear in mind, when considering the issue of given and new information in discourse, that the speaker/ writer who decides what information should be considered given or new. Halliday (1985, 1994, 2012) and Halliday \& Matthiessen 
(2004) suggest that characteristically the speaker/writer will order given information before new information. They maintain that this should be considered a rule of thumb. Thus, in the clause I met a traveller from an antique land, the assumed or given knowledge is that "I met someone" and the new information is that "it was the traveller from an antique land that was met".

Halliday $(1985,1994,2012)$ and Halliday \& Matthiessen (2004) further suggest that there is a close semantic relationship between thematic structure and information structure. All things being equal, a speaker will choose the Theme from within what is Given and locate the New somewhere within the Rheme. This way of patterning the textual clause is referred to as the unmarked (usual) case. Thus, in the clause $I$ met a traveller from an antique land, I functions as Theme/Given and met a traveller from an antique land as Rheme/New, represented as follows:

\begin{tabular}{|c|c|}
\hline$I$ & $\begin{array}{c}\text { met a traveller from an } \\
\text { antique land }\end{array}$ \\
\hline Theme & Rheme \\
\hline Given $\longrightarrow$ New \\
\hline
\end{tabular}

There are cases, however, in which Theme/Given and Rheme/New are not conflated. This way of patterning is referred to as marked case, exemplified as follows:

\begin{tabular}{|c|c|}
\hline A traveller from an antique land, & I met \\
\hline Theme & Rheme \\
\hline New- Given \\
\hline
\end{tabular}

(For more details of the concepts Theme, Rheme, Given and New, see Halliday, 1994, Chapter 3; Halliday \& Matthiessen, 2004, Chapter 3; Fries, 1981; and Hoang, 2007).

\subsubsection{Groups and phrases}

Below the clause, there are groups and phrases having different functions in the experiential, interpersonal and textual clause. For the purpose of this review, however, two groups and one phrase are in focus: nominal group, verbal group and prepositional phrase. Nominal group is a group of nominal words which serves as participant roles (Actor, Goal, Behaver, Range, Senser, Phenomenon, etc.), in the experiential clause and Subject or Complement in the interpersonal clause. Experientially, a nominal group is organized by one or more of the functional elements such as Deictic, Numerative, Epithet and Classifier which precede the head noun serving as Head/ Thing and Qualifier(s) which follow(s) the Head/Thing. Unlike the functional elements that precede the Head/Thing, which are words or word complexes, the Qualifier is either a phrase or a clause. Halliday (1994: 180) provides a good example of the English nominal group which can be reproduced below for illustration:

\begin{tabular}{|c|c|c|c|c|c|c|}
\hline those & two & splendid & old & electric & trains & with pantographs \\
\hline Deictic & Numerative & Epithet 2 & Epithet 1 & Classifier & Head/Thing & Qualifier \\
\hline
\end{tabular}

Verbal group is the constituent serving as Process in the transitivity structure and Predicator in the mood structure. In terms of experiential structure, it has lexical (main) verbs having the function of Event and grammatical verbs, including modal verbs such as can, may, must, having the function of
Finite/Auxiliary (in English) and Auxiliary (in Vietnamese). Below is an example of a verbal group in Vietnamese:

\begin{tabular}{|c|c|c|}
\hline có thế & se & hát \\
\hline may be & shall/will & sing \\
\hline $\begin{array}{c}\text { (modal) } \\
\text { Auxiliary 1 }\end{array}$ & $\begin{array}{c}\text { (modal) } \\
\text { Auxiliary 2 }\end{array}$ & Event \\
\hline
\end{tabular}


Prepositional phrase consists of a preposition plus a nominal group, such as into the air in I shot an arrow into the air (from "I Shot an Arrow into the Air" by Longfellow). A prepositional phrase can be treated as a mini-clause. The reason is that unlike group, the structure of a prepositional phrase is like the transitivity structure of the clause in which the preposition functions as Minorprocess and the nominal group as Minirange. Thus in into the air, into functions as Minorprocess and the air as Minirange (see Matthiessen et al, 2010).

\section{Research design and methodology}

\subsection{Data collection}

The source poem "Bánh trôi nước" by Hồ Xuân Hương and the three English versions of translation: "The Floating Cake" translated by John Balaban, "The Cake That Drifts in Water" translated by Huỳnh Sanh Thông, and "Floating Sweet Dumpling" translated by Marylin Chin were collected from http://www. chopsticksalley.com/single-post/2016/10/03/ A-Tale-of-Three-Translations-in-Poetry. The source poem was then double-checked and reedited to ensure its originality.

\subsection{Data analysis}

The analysis of the source poem and the three translated versions will follow the following steps:

i. the source poem is analyzed in terms of field, tenor, and mode to relate the elements of context to the components of meaning in the text,

ii. the source poem and the three translated versions are analyzed for baseline information,

iii. the source poem and the three translated versions are analyzed for transitivity, mood and theme to uncover their experiential, logical, interpersonal and textual meanings,

iv. the findings obtained from the analysis are discussed and compared to establish the similarities and differences between the three translated versions and the source poem, and between the translated versions.

\subsubsection{Contextual analysis of "Bánh trôi nước"}

The context of situation of a written text tends to be complex and that of "Bánh trôi nước" is about as complex as it is possible for it to be. Based on Halliday \& Hasans' (1985) conceptual framework, the context of situation in which the source poem functions can be briefly described as follows:

\begin{tabular}{|c|l|}
\hline Field: & $\begin{array}{l}\text { A lyric (poem) describing a rice flour cake that the Vietnamese serve in thickened } \\
\text { coconut milk or syrup. Literally, it is about food; but figuratively, the cake becomes } \\
\text { a metaphor signifying the hard and vagabond plight of a Vietnamese feudal woman. }\end{array}$ \\
\hline Tenor: & $\begin{array}{l}\text { Poetess to general readers, readers unseen, poetess addresses herself to readers } \\
\text { intimately and assigns their role as senior/older, and adopts her role as junior/ } \\
\text { younger }(\mathrm{em}) . \\
\text { Poetess as describer of the cake encoded in declarative clauses where the sense is } \\
\text { that is how I }(\mathrm{em}) \text { in the name of the cake am, and despite my hard and vagabond } \\
\text { life, I am resolute to be a faithful/loyal woman. }\end{array}$ \\
\hline Mode: & $\begin{array}{l}\text { Written to be recited or read; text as "self-sufficient" as only form of social action } \\
\text { by which situation is defined. }\end{array}$ \\
\hline
\end{tabular}




\subsubsection{Baseline data analysis}

To get baseline information for further analysis and discussion, the source poem and the three translated versions are counted for the number of words; then they are analyzed for the number of clause complexes, the number of clauses (clause simplexes), and the number of embedded clauses. Due to the fact that there are no softwares for doing these things in Vietnamese, but fortunately, the source poem and the three versions of translation are all short, the counting and the analysis are done manually. Following Halliday (1985, 1994), Halliday \& Matthiessen (2004), and Hoang $(2005,2006)$, I shall use the following notational conventions in my analysis:

- Three vertical strokes || $\mid$ to indicate the boundary of the clause complex

- Two vertical strokes $\|$ to indicate the boundary of the clause (clause simplex)

- Double square brackets [[ ]] to indicate the boundary of the embedded clause

- Roman numerals I, II,... to indicate the number of clause complex

- Arabic numerals $1,2, \ldots$ to indicate the number of clause (simplex)
- The Greek letter $\alpha$ to indicate the paratactic (main) clause in relation to the hypotactic (subordinate) clause in a clause complex

- The Greek letter $\beta$ to indicate the hypotactic (subordinate) clause in relation to the paratactic clause in a clause complex

- The $\operatorname{sign}=$ to indicate the expansion: elaboration relation between clauses in a clause complex

- The sign + to indicate the expansion: extension relation between clauses in a clause complex

- The sign $\mathrm{x}$ to indicate the expansion: enhancement relationship between clauses in a clause complex.

- The sign $\wedge$ to indicate the sequence of elements within a clause.

To avoid confusion that may cause, I shall use "Bánh trôi nước", the source poem, the original poem or the source text interchangeably; but I shall use the Balaban version to refer to the version translated by John Balaban, the Huynh version to the version translated by Huỳnh Sanh Thông, and the Chin version to the version translated by Marilyn Chin. The data baseline analysis of the four texts is provided in Figure 5 below.

\section{Bánh trôi nước}

(I) $\|^{1} \alpha$ Thân em vừa trắng lại vừa tròn

$\|^{2}+\beta 1$ Bảy nổi $\|^{3}+\beta 2$ ba chìm với nước non $\|$

(II) $\mid \|^{4} x 1$ Rắn nát mặc dầu tay kẻ nặn

|| ${ }^{5} 2$ Mà em vẫn giữ tấm lòng son || (25 words)

\section{The Balaban version (The Floating Cake)}

(I) $\|\left.\right|^{1} \alpha 1$ My body is white; $\|^{2}+\alpha 2$ my fate, softly rounded,

$\|^{3}+\beta 1$ Rising $\|^{4}+\beta 2$ and sinking like mountains in streams.

(II) $\|\left.\right|^{5} \mathrm{x} 1$ Whatever way hands may shape me,

$\|^{6} 2$ At center my heart is red and true.|| (32 words) 


\section{The Huynh version (The Cake That Drifts In Water)}

$\|^{1}$ My body is both white and round

(I) \|\|$^{2} 1$ In water I now swim, $\|^{3}+2$ now sink.

(II) $\|{ }^{4} \mathrm{x} 1$ The hand $+[$ that kneads me]] may be rough-

$\|^{5} 2$ I still shall keep my true-red heart || (35 words)

\section{The Chin version (Floating Sweet Dumpling)}

||| $\left.\right|^{1}$ My body is powdery white and round

(I) $\|^{2} 1$ I sink $\|^{3}$ and +2 bob like a mountain in a pond

(II) $\|\left.\right|^{4} \times 1$ The hand $+[[$ that kneads me]] is hard and rough

$\|^{5} 2$ You can't destroy my true red heart ||| (36 words)

Figure 5. Baseline data analysis

As can be seen in Figure 5, both the source poem and the three translated versions are organized in five lines including the title. According to our analysis, "Bánh trôi nước" has the total number of 25 words, five clauses structured in 2 clause complexes of which complex (I) consists of three clauses: ||| ${ }^{1}$ Thân em vìa trắng lại vùa tròn $\|^{2}$ Bảy nổi $\|^{3}$ ba chìm với nước non $\|$, and

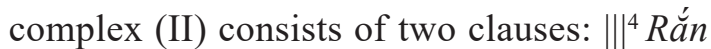
nát mặc dầu tay kẻ nặn $\|^{5}$ Mà em vẫn giũu tấm lòng son $\|$, and no embedded clause. The Balaban version has the total number of 32 words, six clauses structured in two clause complexes of which complex (I) consists of four clauses: $\|{ }^{1}$ My body is white; $\|^{2}$ my fate, softly rounded, $\|^{3}$ Rising $\|^{4}$ and sinking like mountains in streams $\mid \|$, and complex (II) consists of two clauses: I|| Whatever way hands may shape me, $\|^{6}$ At center my heart is red and true. $\|$, and no embedded clause. The Huynh version has the total number of 35 words, five clauses structured in one independent clause: $\|{ }^{1}$ My body is both white and round $\|$, and two clause complexes of which complex (I) consists of two clauses: $\|\left.\right|^{2}$ In water I now swim, $\|{ }^{3}$ now sink. $\| \mid$, and complex (II) consists of two clauses: ||| $\left.\right|^{4}$ The hand [[that kneads me]] may be rough- $\|^{5} I$ still shall keep my true-red heart || $\mid$, and one embedded clause: [[that kneads me ]] in clause 4. And the Chin version has the total number of 36 words, five clauses structured in one independent clause: $\|^{1} M y$ body is powdery white and round $\|$, two clause complexes of which complex (I) consists of two clauses: $\|\left.\right|^{2}$ I sink $\|^{3}$ and bob like a mountain in a pond III, and complex (II) consists of two clauses: (II) $\mid \|^{4}$ The hand [[that kneads me]] may be hard and rough $\mid{ }^{5}$ You can't destroy my truered heart III, and one embedded clause: [[that kneads me]] in clause $4 .{ }^{1}$

The baseline information of "Bánh trôi nước" and the three translated versions can be summarized in Table 1 below.

\footnotetext{
1 There may be some other ways of analysing the source text into clauses and clause complexes. One other way, based on traditional grammar, may treat the first line Thân em vùa trắng lại vùa tròn as a compound sentence which consists of two clauses sharing the same subject Thân em as in Thân em vìa trắng and [Thân em] lại vùra tròn; the second line Bảy nổi ba chìm với nước non as a simple sentence having implicit subject [Em/Thân em] Bảy nổi ba chìm với nuoóc non; and the third and the fourth lines Rắn nát mặc dầu tay kẻ nặn and Mà em vẫn giư tấm lòng son as a complex sentence of which Rắn nát mặc dầu tay kẻ nặn is the subordinate clause and Mà em vẫn giư tấm lòng son is the main clause.
} 
Table 1. "Bánh trôi nước" and the three versions of translation: baseline information

\begin{tabular}{|l|c|c|c|c|}
\hline & $\begin{array}{c}\text { Bánh trôi } \\
\text { nước }\end{array}$ & $\begin{array}{c}\text { The Balaban } \\
\text { version }\end{array}$ & $\begin{array}{c}\text { The Huynh } \\
\text { version }\end{array}$ & $\begin{array}{c}\text { The Chin } \\
\text { version }\end{array}$ \\
\hline Number of words & 25 & 32 & 33 & 36 \\
\hline Number of clause complexes & 2 & 2 & 2 & 2 \\
\hline Number of clause simplexes & 5 & 6 & 5 & 5 \\
\hline Number of embedded clauses & 0 & 0 & 1 & 1 \\
\hline
\end{tabular}

\subsubsection{Transitivity, mood, and theme analysis}

In transitivity, the texts are analyzed for:

(i) types of process: material, behavioural, mental, verbal, relational, and existential

(ii) types of participants in the process

(iii) types of incumbent circumstances

(iv) embedded clauses

In mood, the texts are analyzed for:

(i) types of clause mood: declarative, imperative, and interrogative

(ii) clause mood components: Subject and its semantic features, Finite (in English),
Predicator, Complement, and Adjunct

(iii) types of modality: modalization (probability and usuality) and modulation (obligation and inclination)

In theme, the texts are analyzed for:

(i) types of clause theme: topical/ experiential theme, interpersonal theme, textual theme, single theme, multiple theme, marked theme, and unmarked theme

(ii) themeless clause

(iii) thematic progression

Details of the analysis are provided in Table 2 below.

Table 2. Transitivity, mood and theme analysis of "Bánh trôi nước" and the three translated versions

Bánh trôi nước

\begin{tabular}{|l|l|l|l|}
\hline \multicolumn{1}{|c|}{ (I) } & $\|^{1}$ Thân em & vìa trắng lại vùa tròn \\
\hline Tran & Carrier & $\begin{array}{c}\text { Process: relational } \\
\text { (implicit) }\end{array}$ & Attribute \\
\hline Mood D* & Subject (human; female; junior; intimate) & & Complement \\
\hline Theme & Theme (single; topical; unmarked) & & \\
\hline
\end{tabular}

\begin{tabular}{|l|l|l|}
\hline & $\|\left.\right|^{2}$ Bảy & nổi \\
\hline Tran & Circumstance: extent & Process: material \\
\hline Mood D & Adjunct & Predicator \\
\hline Theme & Rheme & \\
\hline
\end{tabular}




\begin{tabular}{|l|l|l|l|}
\hline & $\|^{3} b a$ & chì & với nước non \\
\hline Tran & Circumstance: extent & Process: material & Circumstance: accompaniment \\
\hline Mood D & Adjunct & Predicator & Adjunct \\
\hline Theme & Rheme & & \\
\hline
\end{tabular}

\begin{tabular}{|l|l|l|l|}
\hline \multicolumn{1}{|c|}{ (II) } & $\mid \|^{4}$ Rắn nát & mặc dầu & tay kẻ nặn \\
\hline Tran & Attribute & & Carrier \\
\hline Mood D & Complement & Adjunct & Subject (human) \\
\hline Theme & Theme (single; topical; marked) & Rheme & \\
\hline
\end{tabular}

\begin{tabular}{|c|c|c|c|c|c|}
\hline & $\|^{5} M a ̀$ & em & vẫn & giü & tấm lòng son $\|$ \\
\hline Tran & & Behaver & & $\begin{array}{l}\text { Process: } \\
\text { behavioural }\end{array}$ & Range \\
\hline Mood D & Adjunct & $\begin{array}{l}\text { Subject (human; female; } \\
\text { junior; intimate) }\end{array}$ & Adjunct & Predicator & Complement \\
\hline Theme & \multicolumn{2}{|c|}{ Theme (multiple; topical; unmarked) } & \multicolumn{3}{|l|}{ Rheme } \\
\hline
\end{tabular}

The Balaban version (The Floating Cake)

\begin{tabular}{|l|l|l|l|l|}
\hline \multicolumn{1}{|c|}{ (I) } & $\mid \|^{1}$ My body & \multicolumn{2}{|c|}{ is } & white; \\
\hline Tran & Carrier & \multicolumn{2}{|c|}{ Process: relational } & Attribute \\
\hline Mood D & Subject (human) & Finite & Predicator & Complement \\
\hline Theme & Theme (single; topical; unmarked) & Rheme & \\
\hline
\end{tabular}

\begin{tabular}{|l|l|l|l|}
\hline & $\|^{2}$ my fate, & & softly rounded \\
\hline Tran & Carrier & (Process: relational) & Attribute \\
\hline Mood D & Subject (human) & & Complement \\
\hline Theme & Theme (single; topical; unmarked) & Rheme & \\
\hline
\end{tabular}

\begin{tabular}{|c|c|c|c|c|}
\hline & \multicolumn{2}{|c|}{\|\|$^{3}$ Rising } & & \\
\hline Tran & \multirow{2}{*}{\multicolumn{2}{|c|}{\begin{tabular}{|l|} 
Proc: material \\
Predicator
\end{tabular}}} & & \\
\hline Mood D & & & & \\
\hline Theme & \multicolumn{2}{|l|}{ Rheme } & & \\
\hline & \|\|$^{4}$ and & sinking & like mountains & in streams \\
\hline Tran & & Process: material & Circumstance: manner & Circumstance: location \\
\hline Mood D & & Predicator & Adjunct & Adjunct \\
\hline Theme & Rheme & & & \\
\hline
\end{tabular}




\begin{tabular}{|c|c|c|c|c|c|}
\hline (II) & $\mid \|^{5}$ Whatever way & hands & \multicolumn{2}{|r|}{ shape } & me \\
\hline Tran & $\begin{array}{l}\text { Circumstance: } \\
\text { manner }\end{array}$ & Actor & \multicolumn{2}{|c|}{ Process: material } & Goal \\
\hline Mood & Adjunct & $\begin{array}{l}\begin{array}{l}\text { Subject } \\
\text { (non-human) }\end{array} \\
\end{array}$ & $\begin{array}{l}\text { Finite (modal: } \\
\text { probability) }\end{array}$ & Predicator & Complement \\
\hline Theme & $\begin{array}{l}\text { Theme (single; topical; } \\
\text { marked) }\end{array}$ & \multicolumn{4}{|l|}{ Rheme } \\
\hline
\end{tabular}

\begin{tabular}{|c|c|c|c|c|c|}
\hline & $\|^{6}$ At center & my heart & & is & red and true $\| \mid$ \\
\hline Tran & Circumstance: location & Carrier & Proces & : relational & Attribute \\
\hline Mood D & Adjunct & Subject (human) & Finite & Predicator & Complement \\
\hline Theme & $\begin{array}{l}\text { Theme (single; topical; } \\
\text { marked) }\end{array}$ & \multicolumn{4}{|l|}{ Rheme } \\
\hline
\end{tabular}

The Huynh version (The Cake That Drifts In Water)

\begin{tabular}{|l|l|l|l|}
\hline & $\|{ }^{1}$ My body & is & both white and round \\
\hline Tran & Carrier & Process: relational & Attribute \\
\hline Mood D & Subject (human) & Finite + Predicator & Complement \\
\hline Theme & Theme (single; topical; unmarked) & Rheme & \\
\hline
\end{tabular}

\begin{tabular}{|l|l|l|l|l|l|}
\hline \multicolumn{1}{|c|}{ (I) } & $\|\left.\right|^{2}$ In water & $I$ & now & \multicolumn{2}{|c|}{ swim, } \\
\hline Tran & Circumstance: location & Actor & Circumstance: time & Process: material \\
\hline Mood D & Adjunct & Subject (human) & Adjunct & Finite & Predicator \\
\hline Theme & $\begin{array}{l}\text { Theme (single; topical; } \\
\text { marked) }\end{array}$ & Rheme & & \\
\hline
\end{tabular}

\begin{tabular}{|l|l|l|}
\hline & $\|^{3}$ now & sink \\
\hline Tran & Circumstance: time & Process: material \\
\hline Mood D & Adjunct & Predicator \\
\hline Theme & Rheme & \\
\hline
\end{tabular}

\begin{tabular}{|l|l|l|l|l|}
\hline \multicolumn{1}{|c|}{ (II) } & $\mid \|^{4}$ The hand $[[$ that kneads $m e]]$ & \multicolumn{1}{|c|}{ may be } & \multicolumn{1}{|c|}{ rough- } \\
\hline Tran & Carrier & Process: relational & Attribute \\
\hline Mood D & Subject (non-human) & $\begin{array}{l}\text { Finite } \\
\text { (modal: probability) }\end{array}$ & Predicator & Complement \\
\hline Theme & Theme (single; topical; unmarked) & Rheme & \\
\hline
\end{tabular}

\begin{tabular}{|c|c|c|c|c|c|}
\hline & $\|^{5} I$ & still & \multicolumn{2}{|c|}{ shall keep } & my true-red heart ||| \\
\hline Tran & Behaver & Circumstance & \multicolumn{2}{|c|}{ Process: behavioural } & Range \\
\hline Mood & Subject (human) & Adjunct & $\begin{array}{l}\text { Finite (modal: } \\
\text { determination) }\end{array}$ & Predicator & Complement \\
\hline Theme & $\begin{array}{l}\text { Theme (single; } \\
\text { topical unmarked) }\end{array}$ & \multicolumn{4}{|l|}{ Rheme } \\
\hline
\end{tabular}


The Chin version (Floating Sweet Dumpling)

\begin{tabular}{|l|l|l|l|l|}
\hline & $\|{ }^{1}$ My body & \multicolumn{2}{|c|}{ is } & powdery white and round \\
\hline Tran & Carrier & Process: relational & Attribute \\
\hline Mood D & Subject (human) & Finite & Predicator & Complement \\
\hline Theme & Theme (single; topical; unmarked) & Rheme & \\
\hline
\end{tabular}

\begin{tabular}{|l|l|l|}
\hline \multicolumn{1}{|c|}{ (I) } & $\|^{2} I$ & \multicolumn{2}{c|}{$\operatorname{sink}$} \\
\hline Tran & Actor & Process: material \\
\hline Mood D & Subject (human) & Finite $\quad$ Predicator \\
\hline Theme & Theme (single; topical; unmarked) & Rheme \\
\hline
\end{tabular}

\begin{tabular}{|l|l|l|l|l|}
\hline & $\|^{3}$ and & bob & like a mountain & in a pond \\
\hline Tran & & Process: material & Circumstance: manner & Circumstance: location \\
\hline Mood D & Predicator & Adjunct & Adjunct \\
\hline Theme & \multicolumn{2}{|l}{ Rheme } & \\
\hline
\end{tabular}

\begin{tabular}{|l|l|l|l|l|}
\hline \multicolumn{1}{|c|}{ (II) } & $\mid \|^{4}$ The hand $[[$ that kneads me $]]$ & \multicolumn{2}{|c|}{ is } & hard and rough \\
\hline Tran & Carrier & Process: relational & Attribute \\
\hline Mood D & Subject (non-human) & Finite $\quad$ Predicator & Complement \\
\hline Theme & Theme (single; topical; unmarked) & Rheme & \\
\hline
\end{tabular}

\begin{tabular}{|l|l|l|l|l|}
\hline & $\|^{5} Y o u$ & \multicolumn{1}{|c|}{ can't destroy } & my true red heart \|\| \\
\hline Tran & Actor & Process: material & Goal \\
\hline Mood & Subject (human) & Finite (modal: inability) & Predicator & Complement \\
\hline Theme & $\begin{array}{l}\text { Theme } \\
\text { (single; topical; unmarked) }\end{array}$ & Rheme & \\
\hline
\end{tabular}

D* = Declarative

\subsection{Discussion and comparison}

\subsubsection{Transitivity patterns of "Bánh trôi nuoóc" and the three translated versions}

The transitivity analysis in Table 1 shows that of the five processes (clauses) in "Bánh trôi nước", two are relational (clauses $1,4)$, two are material (clauses 2, 3), one is behavioural (clause 5), and no embedded clause; of the six clauses in the Balaban version, three are relational (clauses 1, 2,6), three are material (clauses 3, 4, 5), and no clause is embedded; of the five clauses in the Huynh version, two are relational (clauses 1,4 ), two are material (clauses 2, 3), one is behavioural (clause 5), and one is embedded: that kneads me in clause 4: The hand [[that kneads me]] may be rough; and of the five clauses in the Chin version, two are relational (clauses 1,2), three are material (clauses 2, 3, 
5), and one clause is embedded: that kneads me in clause 4: The hand [[that kneads me]] is hard and rough.

A closer observation shows that quantitatively the Huynh version is more similar to the source poem than the other two translated versions in that both have five processes, of which two are relational, two are material, and one is behavioural. What makes it slightly differ from the source poem is that in clause 4 , there is an embedded clause (relative clause in tradtional grammar) [that kneads me] expanding the meaning of the head nominal group The hand. Ranked second in similarity to the source poem is the Chin version: it is also organized into five processes of which two are relational. What makes it differ from the source poem, however, is that it has three material processes and, like the Huynh version, in clause 4, there is an embedded clause [that kneads me] expanding the meaning of the head nominal group The hand. The biggest difference from the source poem is perhaps the Balaban version. Here instead of representing the poem in five clauses as the source poem, it is organized into six; and unlike the source poem, it has thee relational processes and three material processes.

The quantitative results have revealed enough similarities and differences between the source poem and the translated versions, and between the translated versions themselves. But they still do not tell us much about similarities and differences between them at a more delicate level. To do this, we need one more step: taking a qualitative look at the transitivity pattern and the lexical choice of the texts - what Halliday (1961, cited in Hasan, 1987: 184) refers to as "most delicate grammar". We will go through the source text and the translated versions line by line.
The first line. Our transitivity analysis in Table 1 shows that the first line in the source poem Thân em vì̀a trắng lai vì̀a tròn is a relational process having the transitivity pattern of Carrier $\wedge$ Process: relational $\wedge$ Attribute, in which the Carrier is realized by a nominal group consisting of the noun Thân (body) functioning as Head/Thing and the noun em ( $I$ [junior/younger]) functioning as Qualifier (post modifier in traditional grammar), the relational Process is implicit, and the Attribute is realized by two adjectives in parallel paratactic relation (vì̀a) trắng (both white) and (lại vìa ) tròn (and round).

A similar transitivity pattern and lexical choices can be found in the first line in the Huynh version My body is both white and round. It is also a relational process having the pattern of Carrier $\wedge$ Process: relational $\wedge$ Attribute, in which the Carrier is realized by a nominal group consisting of the possessive adjective My functioning as Deictic and the noun body functioning as Head/Thing, the relational Process is realized by the copula verb is, and the Attribute is realized by two adjectives in parallel paratactic relation (both) white and (and) round.

Similar to the source poem, the first line in the Chin version My body is powdery white and round is also a relational clause having the transitivity pattern of Carrier ${ }^{\wedge}$ Process $\wedge$ Attribute, in which the Carrier is realized by the a nominal group consisting of the possessive adjective $M y$ functioning as Deictic and the noun body functioning as Head/Thing, the relational Process is realized by the copula verb is, and the Attribute is realized by three adjectives powdery, white, and round. What makes it differ from the source clause lies in the representation of the Attribute where we find one more quality whose correspondence is not found in the source clause is added powdery in powdery white and round. 
The biggest difference from the source line is perhaps the Balaban version. Here instead of representing the The Floating Cake and its two qualities in one relational clause as in the source poem, the Balaban version constructs the first line in the poem into two clauses \|\|$^{1}$ My body is white; $\|^{2}$ my fate, softly rounded $\|$. Clause 1 is a relational process having the pattern of Carrier $\wedge$ Process: relational $\wedge$ Attribute, in which the Carrier is realized by a nominal group consisting of the personal possessive adjective $M y$ functioning as Deictic and the noun body functioning as Head/Thing, the relational Process is realized by the copula verb is, and the Attribute is realized by the adjective white. The second clause is also a relational process which has the pattern of Carrier $\wedge$ Process: relational $\wedge$ Attribute, in which $m y$ fate whose correspondence is not found in the source poem is realized by a nominal group consisting of the personal possessive adjective my functioning as Deictic and the noun fate functioning as Head/Thing, the relational Process is absent, and the Attribute is realized by a participial phrase consisting of the adverb softly and the participial adjective rounded. Note that although both round and softly rounded can function as Attribute in a relational clause, they differ in their delicate experiential meaning: while round, which can correspond to tròn in the source clause, is an adjective expressing the inherent state/ quality of a thing, rounded is a passive verb form representing the affected state of the Carrier. So judging from these differences in both transitivity patterning and lexical choice, the equivalence of the clause complex in the Balaban version My body is white; my fate, softly rounded to the clause of the source poem Thân em vì̀a trắng lại vùa tròn can be questioned.
The second line. Our analysis in Table 1 shows that the second line in the source text consists of two material clauses: $\|^{2} B a ̉ y$ nổi $\|$ and $\|^{3}$ ba chìm với nước non $\|$. The first clause (clause 2) has the transitivity pattern of Circumstance: extent ${ }^{\wedge}$ Process: material, in which the Circumstance is realized by the Numerative $B a b y$ and the material Process is realized by the action verb nổ; and the second clause (clause 3 ) has the transitivity pattern of Circumstance: extent ${ }^{\wedge}$ Process: Material $\wedge$ Circumstance: accompaniment, in which the Circumstance, like clause 2, is realized by the Numerative $b a$, the material Process is realized by the action verb chim, and the Circumstance by a prepositional phrase consisting of the preposition vori and the compound noun nước non. ${ }^{2}$

Like the source text, the second line in the Balaban version also consists of two material clauses $\|^{2}$ Rising $\|^{3}$ and sinking like mountains in streams $\|$. The first clause (clause 2) has the transitivity pattern of Process: material which is realized by the action verb Rising; and the second clause (clause 3 ) has the transitivity pattern of Process: material ${ }^{\wedge}$ Circumstance:

\footnotetext{
It should be noted that bảy nổi ba chìm is a shortened variant of the expression ba chìm bảy nổi chín lênh đênh. Literally, this expression construes three states of affairs: ba chìm (three times submerge), bảy nổi (seven times emerge) and chín lênh đênh (nine times drift). Figuratively, however, they have been metaphorized to refer to "the plight of a drifting, hard, unlucky and now-up-and-now-down life" (Hoang et al., 2002: 30). Seen from this point of view, Bảy nổi ba chìm với nước non can be treated as a material clause which has the transitivity pattern of Process: material (Bảy nổi ba chìm) ${ }^{\wedge}$ Circumstance: accompaniment (với nước non). However, the figurative meaning of bảy nổi ba chìm can still be perceived as consisting of two material processes as analysed in Table 1: Bảy nổi and $b a$ chìm vói nưóc non.
} 
manner, in which the process is realized by the action verb sinking and the Circumstance by the a prepositional phrase consisting of the preposition like, the plural noun mountains and the prepositional phrase functioning as Qualifier consisting of the preposition in and the plural noun streams. At the more delicate level (group and lexical level), we can see discrepancies in this line in the Balaban version as compared to that of the source text. Here in clause 2, we only find the process Rising which corresponds to nổ in the source clause, while the element that corresponds to the Circumstance Bảy (seven times) in the source clause is not found. The same thing can be observed in clause 4. Here we only find the process sinking which corresponds to chim in the source clause, while the Circumstance $b a$ (three times) in the source clause is not found either. What makes clause 3 in the Balaban version differ more markedly from the source poem lies in both the function and the delicate meaning of like mountains in streams. The analysis in Table 1 shows that like mountains in streams functions as Circumstance of manner: comparison, while vói nưóc non in the source poem functions as Circumstance of accompaniment. Seen from the point of view of our analysis, whether like mountains in streams is equivalent to với nước non in the source text is open to question.

In the Huynh version, the second line is also constructed in two material clauses $\|\left.\right|^{2}$ In water I now swim $\|^{3}$ now sink $\|$. What makes it differ from the source line is that instead of constructing the two clauses in the same pattern of Circumstance: extent (Bảy) ^ Process: material (nổi) and Circumstance: extent $(b a) \wedge$ Process: material (chim) $\wedge$ Circumstance: manner (vói nuóc non), the first clause (clause 2) of the Balaban version has the transitivity pattern of Circumstance: location $(\text { In water })^{\wedge}$ Actor $(I)^{\wedge}$ Circumstance: time (now) $\wedge$ Process: material (swim), and the second clause (clause 3), Circumstance: time $(\text { now })^{\wedge}$ Process: material (sink). At the more delicate level, except for the action verb sink which may correspond to chim in the source line, all the remaining items In water, I, now, swim, and now do not have correspondences in the source line.

The second line in the Chin version is also constructed in two material clauses $\|^{2} I$ sink $\|^{3}$ and bob like a mountain in a pond $\|$. But unlike the source poem and the other two translated versions, the first clause (clause 2) has the transitivity pattern of Actor $(I)^{\wedge}$ Process: material (sink), and the second clause (clause 3 ) has the pattern of Process: material $(b o b) \wedge$ Circumstance of manner (like a mountain in a pond). A closer examination of the line reveals that except for the two action verbs sink and bob, which may correspond to chìm and nổ respectively in the source line, other items such as I, like a mountain in a pond do not seem to have correspondences in the source line, and in particular items that render the meaning of $B a \mathfrak{y} y$ (seven times), $b a$ (three times), vói nước non (with water) in the source line are not found.

The third line. The third line in the source poem Rắn nát mặc dầu tay kẻ nặn is a relational clause which has the transitivity pattern of Attribute $($ Rắn nát) $\wedge$ (Process: relational) $\wedge$ Carrier (tay kẻ nặn), in which the Attribute is realized by an adjectival group of two adjectives in implicit paratactic relation Rắn nát (hard and/or soft), the relational Process is implicit in the clause, and the Carrier is realized by a nominal group consisting of the noun tay (hand) functioning as Head/Thing and the noun ke nặn (maker/ shaper) functioning as Qualifier. 
The third line in the Balaban version Whatever way hands may shape me is also a clause, but quite different from the source clause, it is a material process which has the transitivity pattern of Circumstance: manner $\wedge$ Actor ${ }^{\wedge}$ Process: material ${ }^{\wedge}$ Goal, in which the Circumstance of manner is realized by a nominal group consisting of the pronoun whatever functioning as Deictic and the noun way functioning as Head/Thing, the Actor is realized by the plural noun hands, the material Process is realized by a verbal group consisting of the modal auxiliary verb may and the main action verb shape, and the Goal is realized by the first personal pronoun used in the objective case me. At the lexical level, only two items whose correspondence to the source clause can be established: hands may correspond to tay (kẻ nặn), and shape to nặn. The remaining items Whatever way, may, and me have no correspondences in the source clause.

Similar to the source clause, the third line in the Huynh version The hand that kneads me may be rough is a relational clause. What makes it differ from the source clause, however, is that unlike the clause of the source text which has the pattern of Attribute ${ }^{\wedge}$ (Process: relational) ${ }^{\wedge}$ Carrier, it is represented in the order of Carrier (The hand that kneads me) $\wedge$ Process: relational (may be) ${ }^{\wedge}$ Attribute (rough), in which the Carrier is realized by a nominal group consisting of the definite article The functioning as Deictic, the singular noun hand functioning as Head/ Thing and the embedded relative clause that kneads me (elaborating the meaning of hand) functioning as Qualifier, the relational Process is realized by a verbal group consisting of the modal auxiliary verb may and the copula verb be, and the Attribute is realized by the adjective rough. A closer examination of the lexical item realizing the Attribute reveals that the choice of rough has no correspondence either to rắn or nát in the source clause.

Similar to the source clause, the third line in the Chin version The hand that kneads me is hard and rough is also a relational clause. What makes it differ from the clause of the source poem is that, like the Huynh version, it has the pattern of Carrier (The hand that kneads me $)^{\wedge}$ Process: relational (is)^ Attribute (hard and rough), in which the Carrier is realized by a nominal group consisting of the definite article The functioning as Deictic, the singular noun hand functioning as Head/ Thing and the embedded relative clause that kneads me (elaborating the meaning of hand) functioning as Qualifier, the relational Process is realized by a copula verb is, and the Attribute is realized by an adjectival group of two adjectives in paratactic relation hard and rough. A closer examination of the lexical items realizing the Attribute reveals that hard may correspond to rắn while rough does not correspond to nát in the source clause.

The fourth line. The fourth line in the source poem Mà em vẫn giữ tấm lòng son is a behavioural clause which has the transitivity pattern of Behaver $(\mathrm{em})^{\wedge}$ Circumstance $(v \hat{a} n)$ $\wedge$ Process: behavioural (giũ) $\wedge$ Range (tấm lòng son), in which the Behaver is realized by the noun em, the Circumstance by the adverb vẫn, the behavioural Process by the verb giũ , and the Range by a nominal group comprising the Head/Thing tấm lòng and the Epithet son.

The fourth line in the Balaban version $A t$ center my heart is red and true is also a clause, but unlike the source clause, it is a relational clause which has the pattern of Circumstance: location $($ At center $) \wedge$ Carrier (my heart) ${ }^{\wedge}$ Process: relational (is) $\wedge$ Attribute (red and true), in which the Circumstance of location is realized by a prepositional phrase consisting of the preposition At and the noun center, 
the Carrier is realized by a nominal group consisting of the personal possessive adjective my functioning as Deictic and the noun heart functioning as Head/Thing, the relational Process is realized by the copula verb is, and the Attribute is realized by an adjectival group consisting of two Epithets in paratactic relation red and true. A closer examination reveals that because the content in this line is represented in a process different from that in the source line, only some lexical items whose correspondence to those in the source line can be established. Here we can find heart may correspond to tấm lòng, and true to son. Other items such as $A t$ center, is, and red do not have correspondences in the source clause.

Similar to the source poem, the fourth line in the Huynh version I still shall keep my true-red heart is a behavioural clause which has the transitivity pattern of Behaver $(I)^{\wedge}$ Circumstance (still) $\wedge$ Process: behavioural $(\text { keep })^{\wedge}$ Range (my true-red heart), in which the Behaver is realized by the first personal pronoun $I$, the Circumstance is realized by the adverb still, the behavioural Process is realized by a verbal group consisting of the modal auxiliary verb shall and the main behavioural verb keep, and the Range is realized by a nominal group consisting of the noun heart functioning as Head/Thing, the compound adjective true-red functioning as Epithet, and the personal possessive adjective $m y$ functioning as Deictic. A closer observation reveals that several lexical items whose correspondence to those in the source line can be established. Here we find I may correspond to em, still to vẫn, keep to giũ , and heart to tấm lòng. Other items such as my and true-red do not seem to have correspondences in the source line.

Unlike the source poem and the Huynh version, the fourth line in the Chin version You can't destroy my true red heart is a material clause which has the transitivity pattern of Actor $(\mathrm{You}) \wedge$ Process: material (can't destroy) ${ }^{\wedge}$ Goal (my true red heart), in which the Actor is realized by the second personal pronoun You, the material Process is realized by a verbal group which consists of the modal auxiliary verb can't and the action verb destroy, and the Goal is realized by a nominal group consisting of the personal possessive adjective my functioning as Deictic, the two adjectives true red functioning as Epithets, and the noun heart functioning as Head/ Thing. A closer examination reveals that because the content in this line is represented in a process different from that in the source line, except for the noun heart which may correspond to tấm lòng, the other items such as you, can't, destroy, my, and true red do not have correspondences in the source line.

Table 3 summarizes the main similarities and differences between "Bánh trôi nước" and the three versions of translation in terms of transitivity.

Table 3. Transitivity patterns of "Bánh trôi nước" and the three versions of translation

\begin{tabular}{|c|c|c|c|c|}
\hline Process types & $\begin{array}{c}\text { Bánh trôi } \\
\text { nước }\end{array}$ & $\begin{array}{c}\text { The Balaban } \\
\text { version }\end{array}$ & $\begin{array}{c}\text { The Huynh } \\
\text { version }\end{array}$ & $\begin{array}{c}\text { The Chin } \\
\text { version }\end{array}$ \\
\hline Number of clause & 5 & 6 & 5 & 5 \\
\hline Material & 2 & 3 & 2 & 3 \\
\hline Relational & 2 & 3 & 2 & 2 \\
\hline Behavioural & 1 & 0 & 1 & 0 \\
\hline Embedded & 0 & 0 & 1 & 1 \\
\hline
\end{tabular}


4.3.2. Clause complexing patterns of "Bánh trôi nước" and the three translated versions

As shown in our baseline analysis in Figure 5, Section 3.2.2, the whole source poem consists of two clause complexes. Complex I (lines 1 and 2) consists of three clauses (clauses 1, 2 and 3). The relationship between clauses 2 and 3 and clause 1 is that of hypotactic expansion: extension (clauses 2 and 3 extend the meaning of clause 1); and the relationship between clause 2 and clause 3 is that of paratactic expansion: extension (clause 3 extends the meaning of clause 2). The complexing pattern of complex I can be represented as $\alpha^{\wedge}+\beta\left(\beta 1^{\wedge}+\beta 2\right)$ actualized in $\|^{1} \alpha$ Thân em vì̀a trắng lại vùa tròn $\wedge \|^{2}$ $+\beta\left(\beta 1\right.$ Bảy nổi $\|^{3}+\beta 2$ ba chìm với nưóc non $)$ ||l. Complex II (lines 3 and 4) consists of two clauses (clauses 4 and 5). The relationship between them is that of paratactic expansion: enhancement (clause 4 enhances the meaning of clause 5). The complexing pattern of complex II can be represented as $\mathrm{x} 1 \wedge 2$ actualizing in $\|\left.\right|^{4} \mathrm{x} 1$ Rắn nát mặc dầu tay kẻ nặn $\|^{5}{ }^{2}$ Mà em vẫn giũ tấm lòng son $\|$.

The Balaban version is also constructed into two clause complexes. But unlike the source poem, complex I (lines 1 and 2) consists of 4 clauses which have different layers of complexing and thus having different logico-semantic relationships. Our analysis in Figure 5 shows that two clauses in line 1 form a paratactic clause complex of expansion: extension relationship which has the complexing pattern of $1^{\wedge}+2$ actualized in $\|\left.\right|^{1} 1$ My body is white; $\wedge \|^{2}+2$ my fate, softly rounded, II; and two remaining clauses in line 2 form another paratactic clause complex of expansion: extension relationship which has the complexing pattern of $1^{\wedge}+2$ actualized in $\|\left.\right|^{3}+1$ Rising $\wedge \|^{4}+2$ and sinking like mountains in streams. |||. The paratactic clause complex in line 1 and the paratactic clause complex in line 2 form a hypotactic clause complex of expansion: extension relationship, yielding the total complexing pattern of $\alpha\left(\alpha 1^{\wedge}+\alpha 2\right)$ ${ }^{\wedge}+\beta\left(\beta 1^{\wedge}+\beta 2\right)$ actualized in $\|\left.\right|^{1} \alpha(\alpha 1$ My body is white; $\wedge^{\wedge} \|^{2}+\alpha 2$ my fate, softly rounded, $)^{\wedge} \|^{3}$ $\beta\left(\beta 1\right.$ Rising $\|^{4 \wedge}+\beta 2$ and sinking like mountains in streams.) ||l. And complex II (lines 4 and $5)$, like the source poem, consists of 2 clauses (clauses 5 and 6) of expansion: enhancement relationship which has the complexing pattern of $\mathrm{x} 1 \wedge 2$ actualized in $\|\left.\right|^{5} \mathrm{x} 1$ Whatever way hands may shape me, $\wedge \|^{6} 2$ At center my heart is red and true.|||.

Similar to the source poem and the Balaban version, the Huynh version is also constructed into two clause complexes. Like the source poem, it begins with a clause, but unlike the source poem this clause does not enter into complexing relationship with the other two clauses in line 2. Instead, clauses 2 and 3 (line 2) in the Huynh version form a paratactic clause complex (complex I) of expansion: extension relationship which has the complexing pattern of $1^{\wedge}+2$ actualized in $\|\left.\right|^{2} 1$ In water I now swim ${ }^{\wedge} \|^{3}+2$ now sink II. And clause 4 (line 4) and clause 5 (line 5) form another paratactic clause complex (complex II) of expansion: enhancement relationship which has the complexing pattern of $\mathrm{x} 1^{\wedge} 2$ actualized in \|\|$^{4} \mathrm{x} 1$ The hand $[[$ that kneads me]] may be rough $\wedge \|^{5} 2$ I still shall keep my true-red heart || .

Like the source poem, the Balaban version, and the Huynh version, the Chin version is also constructed into two clause complexes. Similar to the source poem and the Huynh version, the Chin version begins with a clause. Unlike the source poem, but much like the Huynh version this clause in the Chin version does not enter into complexing relationship with the other two clauses in 
line 2. Instead, clauses 2 and 3 (line 2) form a paratactic clause complex (complex I) of expansion: extension relationship which has the complexing pattern of $1^{\wedge}+2$ actualized in \|\|$^{2} 1$ I sink $k^{\wedge} \|^{3}+2$ and bob like a mountain in a pond $\mid \|$. And clause 4 (line 4 ) and clause 5 (line 5) form the second paratactic clause complex (complex II) of expansion: enhancement relationship which has the complexing pattern of $\mathrm{x} 1^{\wedge} 2$ actualized in \|\|$^{4} \mathrm{x} 1$ The hand $[[$ that kneads me]] is hard and rough ${ }^{\wedge} \|^{5} 2$ You can't destroy my true red heart || $\mid$.

The main similarities and differences between "Bánh trôi nước" and the three versions of translation in terms of clause complexing can be summarized in Table 4 below.

Table 4. Clause complexing patterns of the source poem and the three translated versions

\begin{tabular}{|c|c|}
\hline "Bánh trôi nước": & Complex I: $\alpha^{\wedge}+\beta\left(\beta 1^{\wedge}+\beta 2\right)^{\wedge}$ complex II: $\mathrm{x} 1^{\wedge} 2$ \\
\hline The Balaban version: & Complex I: $\alpha\left(\alpha 1^{\wedge}+\alpha 2\right)^{\wedge}+\beta\left(\beta 1^{\wedge}+\beta 2\right)^{\wedge}$ complex II: $\mathrm{x} 1^{\wedge} 2$ \\
\hline The Huynh version: & Simplex $1^{\wedge}$ complex I: $1^{\wedge}+2^{\wedge}$ complex II: $\mathrm{x} 1^{\wedge} 2$ \\
\hline The Chin version: & Simplex $1^{\wedge}$ complex I: $1^{\wedge}+2^{\wedge}$ complex II: $x 1^{\wedge} 2$ \\
\hline
\end{tabular}

\subsubsection{Mood patterns of "Bánh trôi nước" and} the three translated versions

As with transitivity and clause complexing, in this section we will begin our mood discussion and comparison with the source poem. Our mood analysis in Table 1 shows that all the five clauses of "Bánh trôi nước" are declarative, of which two are Subjectless (clauses 2 and 3) and three have Subject (clauses 1, 4, and 5). Our analysis also indicates that all three Subjects in the poem have the feature of "human": Thân em (clause 1), tay kẻ nặn (clause 4), and em (clause 5) and that except for the Subject in clause 4, the two others have four additional features of "female", "non-possessive", "junior/younger" and "intimate": Thân em (clause 1) and em (clause 5). What seems to be a prominent feature of the source poem is that all its five clauses are non-modalized.

In contrast, of the six clauses in the Balaban version, five are declarative (clauses $1,2,3,4$, and 6), and one is modalized containing the modal auxiliary verb may expressing probability/possibility (clause
5). In terms of Subject, two clauses are Subjectless (clauses 3 and 4) and four have Subject (clauses 1, 2, 5, and 6). Our analysis in Table 1 shows that of the four Subjects in the Balaban version, one has the feature of "non-human": hands (clause 5) and three have the features of "human" and "possessive": $M y$ body (clause 1), my fate (clause 2), and my heart (clause 6). But what makes the human Subjects in the Balaban version differ from those in the source poem is that they do not have the features "female", "junior/younger" and "intimate".

Of the five clauses in the Huynh version, three are declarative (clauses 1, 2, and 3); and, different from the source poem and the Balaban version, two clauses are modalized, one containing the modal auxiliary verb may expressing probability/possibility (clause 4), and the other the modal auxiliary verb shall expressing determination (clause 5). Unlike the source poem, in the Huynh version four clauses have Subject of which three have the features of "human": My body (clause 1), $I$ (clause 2) and $I$ (clause 5) and one has the feature of "non-human": The hand that kneads 
me (clause 4). What makes the Subjects in the Huynh version differ from those in the source poem is that like the Balaban version, they only have the feature of "human", while the three other features "female", "junior/ younger" and "intimate" are not present.

The Chin version provides a somewhat different interpersonal picture as compared with the source poem. Of the five clauses in this translated version, four are declarative (clauses 1, 2, 3 and 4), and one is modalized containing the modal auxiliary in negative form can't expressing inability (clause 5). Like the Huynh version, of the five clauses, one is Subjectless and four have Subject. Of the four Subjects, three have the features of "human": My body (clause 1), I (clause 2) and You (clause 5), and one has the feature of "non-human": The hand that kneads me (clause 4). Unlike the source poem, but like the Balaban version and the Huynh version, the human Subjects in the Chin version only have the feature "human", the three other features found in the source poem: "female", "junior/younger" and "intimate" are not present. Furthermore, unlike the source poem, the Subject in the Chin version varies from clause to clause. Except for clauses 2 and 3 which share the same Subject $I$, each of the three remaining clauses has a different Subject: My body (clause 1), The hand (clause 4), and You (clause 5). A comparison of these Subjects with those in the source poem reveals that the Subject My body [referring to The Floating Sweet Dumpling] in clause 1 may to some extent correspond to Thân em [referring to Bánh trôi nước] in clause 1 of the source poem; the Subject The hand that kneads me in clause 4 may to some extent correspond to tay kẻ nặn in clause 4 of the source poem. But the shared Subject $I$ in clauses 2 and 3 has no correspondences to clauses 2 and 3 which are Subjectless in the source poem; and the Subject You [referring to the The hand that kneads me] in clause 5 has quite a different meaning from the Subject em [referring to Bánh trôi nước] in the corresponding clause of the source poem.

The main similarities and differences between "Bánh trôi nước" and the three versions of translation in terms of mood can be summarized in Table 5 below.

Table 5. Mood features of "Bánh trôi nước" and the three versions of translation

\begin{tabular}{|c|c|c|c|c|}
\hline Mood category & $\begin{array}{c}\text { Bánh trôi } \\
\text { nước }\end{array}$ & $\begin{array}{c}\text { The Balaban } \\
\text { version }\end{array}$ & $\begin{array}{c}\text { The Huynh } \\
\text { version }\end{array}$ & $\begin{array}{c}\text { The Chin } \\
\text { version }\end{array}$ \\
\hline Number of clause & 5 & 6 & 5 & 5 \\
\hline Declarative & 5 & 3 & 3 & 4 \\
\hline Subject & 3 & 4 & 4 & 4 \\
\hline Modality & 0 & 0 & 2 & 1 \\
\hline
\end{tabular}

4.3.4. Thematic patterns of "Bánh trôi nước" and the three translated versions

Our theme analysis in Table 1 shows that of the five clauses of "Bánh trôi nước", two have single Theme: Thân em (clause 1) and
Rắn nát (clause 4), one has multiple Theme: Mà em (clause 5), three have topical Theme: Thân em (clause 1), Rắn nát (clause 4), (Mà) em (clause 5), none has interpersonal Theme, one has textual Theme Mà (clause 5), two have unmarked Theme: Thân em (clause 1) and 
(Mà) em (clause 5), one has marked Theme: Rắn nát (clause 4), and two are Themeless (clauses 2 and 3). A more detailed analysis of the thematic patterns of the source poem shows that in clause 1, the poetess Hồ Xuân Hương uses Thân em [referring back to Bánh trôi nước in the title] which is single, topical and unmarked Theme/Given as the point of departure of the message and the remaining segment vì̀a trắng lại vừa tròn as Rheme/ New. Neither the Theme nor the Rheme in this clause is picked up in clauses 2 and 3 . In these clauses there are no Themes, and both Bảy nổi and ba chìm với nước non function as Rheme/New. Clause 4 starts with a new Theme which is not connected with any of the Theme or Rhemes in the previous clauses. Here the order of the clause is reversed, and the Complement Rắn nát becomes single, topical but marked Theme/Given [Theme/ Complement] and the remaining segment mặc dầu tay kẻ nặn is Rheme/New. The Theme in clause 1 , however, is picked up as topical Theme in clause 5. Here, Mà em is multiple, topical and unmarked Theme/Given and vấn giư tấm lòng son is Rheme/New. The thematic pattern of the five clauses and their thematic progression pattern in "Bánh trôi nước" can be represented as follows:

\begin{tabular}{|ll|}
\hline$\bullet$ Theme 1 (single/topical/unmarked) & $\wedge$ Rheme 1 \\
$\bullet$ ๑゙* & $\wedge$ Rheme 2 \\
$\bullet$ Ø & $\wedge$ Rheme 3 \\
$\bullet$ Theme 2 (single/topical/marked) & $\wedge$ Rheme 4 \\
$\bullet$ Theme 1 (single/topical/unmarked) & $\wedge$ Rheme 5 \\
\hline
\end{tabular}

*Note: The sign $\varnothing$ indicates the clause has no Theme

The Balaban version provides a different picture of thematic structure. Of the six clauses analyzed in Table 1, four have single Theme: My body (clause 1), my fate (clause 2), Whatever hand (clause 5), and At center (clause 6), none has multiple Theme, four have topical Theme: My body (clause 1), my fate (clause 2), Whatever way (clause 5), and At center (clause 6), none has interpersonal or textual Theme, two have unmarked Theme [Theme/Subject]: My body (clause 1) and my fate (clause 2), two have marked Theme: Whatever way [Adjunct/Theme] (clause 5) and At center [Adjunct/Theme] (clause 6), and two are Themeless (clauses 3 and 4). A closer observation of the thematic patterns of this translated version shows that in clause 1, the translator John Balaban uses My body [referring back to The Floating Cake] which is single, topical and unmarked Theme/Given as the point of departure of the message and the remaining segment is white as Rheme/New. Clause 2 begins with my fate which is also single, topical and unmarked Theme/Given and ends with softly rounded which is Rheme/New. Neither the Theme nor the Rheme in clauses 1 and 2 is picked up in clauses 3 and 4 . In these clauses, like clauses 3 and 4 in the source poem, there are no Themes, and both Rising and and sinking like mountains in streams function as Rheme/New. Clause 5 starts with a new Theme which is not connected with any of the previous Theme or Rhemes. Here Whatever way which is single, topical but marked Theme/Given is used as the point of departure of the message and the remaining segment hands may shape $m e$ as Rheme/New. In a similar manner, clause 6 begins with At center which is single, topical but marked Theme/Given and ends with my heart is red and true which is Rheme/New. The thematic pattern of the six clauses and their thematic progression pattern in the Balaban version can be represented as follows:

- Theme 1 (single/topical/unmarked) ${ }^{\wedge}$ Rheme 1

- Theme 2 (single/topical/unmarked) ^ Rheme 2

$\bullet \emptyset$

$\bullet \emptyset$

$\wedge$ Rheme 3

$\wedge$ Rheme 4

- Theme 5 (single/topical/unmarked) ${ }^{\wedge}$ Rheme 5

- Theme 6 (single/topical/unmarked) ${ }^{\wedge}$ Rheme 6 
In the Huynh version, our analysis in Table 1 shows that of five clauses, four have single Theme: My body (clause 1), In water (clause 2), The hand that kneads me (clause 4) and I (clause 5), none has multiple Theme, four have topical Theme: My body (clause 1), In water (clause 2), The hand that kneads me (clause 4) and $I$ (clause 5), none has interpersonal or textual Theme, three have unmarked Theme: My body (clause 1), The hand that kneads me (clause 4), and $I$ clause (5), one has marked Theme [Adjunct/Theme]: In water (clause 2 ), and one is Themeless (clause 3). A more detailed analysis of this version shows that like the Balaban version, in clause 1 the translator Huỳnh Sanh Thông uses My body [referring back to The Cake that Drifts in Water] which is single, topical and unmarked Theme/Given as the point of departure of the message and the remaining segment is both white and round as Rheme/New. Clause 2 begins with In water which is also single, topical but marked Theme/ Given and ends with I now swim which is Rheme/New. This is followed by clause 3 which only has now sink functioning as Rheme/New. Clause 4 starts with a new Theme which is not connected with any of the Theme or Rheme in the previous clauses. Here the translator places The hand that kneads me as single, topical and unmarked Theme/Given and may be rough as Rheme/New. In clause 5, the translator uses $I$ which is single, topical and unmarked Theme/ Given as the point of departure of the message and the remaining segment still shall keep my true red heart as Rheme/New. The thematic pattern of the five clauses and their thematic progression pattern in the Huynh version can be represented as follows:

\begin{tabular}{ll|}
\hline - Theme 1 (single/topical/unmarked) & $\wedge$ Rheme 1 \\
- Theme 2 (single/topical/unmarked) & $\wedge$ Rheme 2 \\
- Ø & $\wedge$ Rheme 3 \\
- Theme 4 (single/topical/unmarked) & $\wedge$ Rheme 4 \\
- Theme 5 (single/topical/unmarked) & $\wedge$ Rheme 5 \\
\hline
\end{tabular}

It is shown in Table 1 that of the five clauses in the Chin version, four have single Theme: My body (clause 1), I (clause 2), The hand that kneads me (clause 4) and You (clause 5). None has multiple Theme, four have topical Theme: My body (clause 1), I (clause 2), The hand that kneads me (clause 4) and You (clause 5), none has interpersonal or textual Theme, four have unmarked Theme: My body (clause 1); I (clause 2), The hand that kneads me (clause 4), and You (clause 5), none has marked Theme, and one has no Theme. A closer examination shows that like the Balaban version and the Huynh version, in clause 1 the translator uses My body [referring back to Floating Sweet Dumpling] which is single, topical and unmarked Theme/Given as the point of departure of the message and the remaining segment is powdery white and round as Rheme/New. Clause 2 begins with $I$ which is also single, topical and unmarked Theme/Given as the point of departure of the message and the remaining segment sink as Rheme/New. This is followed by clause 3 which has no Theme and the segment and bob like a mountain in a pond functions as Rheme/ New. Clause 4 starts with a new Theme which is not connected with any of Theme or Rheme of the previous clauses. Here, like the Huynh version, the translator places The hand that kneads me as single, topical and unmarked Theme/Given and is hard and rough as Rheme/New. The metaphorised Theme in clause 4 is picked up as Theme in clause 5 . Here You [referring to The hand that kneads $m e]$ which is a single, topical Theme/Given is used as the point of departure of the message and can't destroy my true red heart as Rheme/ New. The thematic pattern of the five clauses and their thematic progression pattern in the Chin version can be represented as follows: 


\begin{tabular}{|ll|}
\hline - Theme 1 (single/topical/unmarked) & $\wedge$ Rheme 1 \\
- Theme 2 (single/topical/unmarked) & $\wedge$ Rheme 2 \\
- Ø & $\wedge$ Rheme 3 \\
- Theme 4 (single/topical/unmarked) & $\wedge$ Rheme 4 \\
- Theme 4 (single/topical/unmarked) & $\wedge$ Rheme 5 \\
\hline
\end{tabular}

Details of Theme showing the similarities and differences between "Bánh trôi nước" and the three versions of translation can be represented in Table 6 below.

Table 6. Details of Theme in "Bánh trôi nước" and the three versions of translation

\begin{tabular}{|c|c|c|c|c|}
\hline Types of theme & $\begin{array}{c}\text { Bánh trôi } \\
\text { nước }\end{array}$ & $\begin{array}{c}\text { The Balaban } \\
\text { version }\end{array}$ & $\begin{array}{c}\text { The Huynh } \\
\text { version }\end{array}$ & $\begin{array}{c}\text { The Chin } \\
\text { version }\end{array}$ \\
\hline Number of clause & 5 & 6 & 5 & 5 \\
\hline Single theme: & 2 & 4 & 4 & 4 \\
Multiple theme: & 1 & 0 & 0 & 0 \\
Topical theme: & 3 & 4 & 4 & 4 \\
Interpersonal theme: & 0 & 0 & 0 & 0 \\
Textual theme: & 1 & 0 & 0 & 0 \\
Unmarked theme: & 2 & 2 & 3 & 4 \\
Marked theme: & 1 & 2 & 1 & 0 \\
Themeless clause: & 2 & 2 & 1 & 1 \\
[single; topical; unmarked]: & 2 & 2 & 3 & 4 \\
[single; topical; marked]: & 1 & 2 & 1 & 0 \\
\hline
\end{tabular}

\section{Conclusion}

\subsection{Summary}

In this paper, we have attempted to make a comparison between three English versions of translation - "The Floating Cake" translated by John Balaban, "The Cake That Drifts In Water" translated by Huỳnh Sanh Thông, and "Floating Sweet Dumpling" translated by Marilyn Chin with a popular Vietnamese poem - "Bánh trôi nước" written by the famous Vietnamese poetess Hồ Xuân Hương. The two research questions we raised for exploration are: (1) "How are the source poem and the translated versions constructed in terms of ideational, interpersonal, and textual meanings?" and (2) "To what extent are the translated versions similar to and different from the source poem and to what extent are the translated versions similar to and different from one another in terms of ideational, interpersonal and textual meanings?" To answer these questions, we have used systemic functional linguistics as the theoretical framework; and based on the compositional feature of language, we have broken down the source poem and the translated versions into smaller meaningful parts: clause complexes, clause simplexes, groups/phrases, and words. Then we counted them, analyzing them in terms of transitivity, mood, and theme, and then comparing them, one by one. In comparing, we have tried to established points of similarities/ equivalents and mismatches/differences between the translated texts and the source text and between the translated texts. It is clear from our comparison that there are both similarities and differences between the translated versions and the source poem and between the translated versions themselves in terms of logico-semantic complexing, transitivity, mood, and theme. To recapitulate, the similarities and differences between the source poem and the three translated versions can be summarized as follows: 
Logically, the source poem is constructed into two clause complexes; the first complex has three clauses constructed in hypotactic relation and the second one has two clauses constructed in paratactic relation. The Balaban version is also constructed into two clause complexes; but instead of three as the source poem, the first complex has four clauses constructed in hypotactic relation and the second one has two clauses constructed in paratactic relation. The Huynh version, in contrast, is constructed into one independent clause and two clause complexes; the first complex has two clauses constructed in paratactic relation, and the second one has two clauses also constructed in paratactic relation. The Chin version, like the Huynh version, is constructed into one independent clause and two clause complexes; the first complex has two clauses constructed in paratactic relation, and the second one has two clauses also constructed in paratactic relation.

Experientially, the source poem is represented in five clauses of which two are relational, two are material, and one is behavioural. In contrast, the Balaban version is represented in six clauses of which three are relational and three are material. Like the source poem, the Huynh version is represented in five clauses of which two are relational, two are material, and one is behavioural. Unlike the source poem and the other two translated versions, the Chin version is represented in five clauses of which two are relational and three are material.

Interpersonally, all five clauses of the source poem are declarative of which two are Subjectless and three have Subjects that have the feature of "human", and two of which have the features of "female", "junior/younger", and "intimate". The Balaban version is constructed into three declarative clauses, two non-finite clauses and one modalized clause. Of the four clauses that have Subject, three have Subjects which have the feature of "human" and one has Subject which has the feature of "non-human". The Huynh version is organized around three declarative clauses and two modalized clauses. Of the four clauses that have Subject, three have the feature of "human" and one has the feature of "nonhuman". The Chin version is organized around four declarative clauses and one modalized clause. Of the five clauses, four have Subject and one is Subjectless. Of the four Subjects, three have the feature of "human" and one has the feature of "non-human". What makes the three translated versions differ from the source text is that the Subjects in these versions only have the feature of "human"; the other features "female", "junior/younger", and "intimate" which the Subjects of the source poem possess are not found in these texts.

Textually, the source poem has three clause themes of which Theme 1 and Theme 5 have (anaphoric) reference to the title: Bánh trôi nước - Thân em - em. The Balaban version has four clause themes of which only Theme 1 has reference to from the title: The Floating Cake - My body. There are two items that have reference to the title but they are placed in the Rheme: me (clause 5) and my heart (clause 6). The Huynh version has four clause themes of which two have reference to the title: The Cake That Drifts in Water - My body (clause 1) - I (clause 5). There are two other items that have reference to the title, but they are placed in the Rheme portion: $I$ (clause 2) and me (clause 4). The Chin version has four clause themes of which two have reference to the title: Floating Sweet Dumpling - My body (clause 1) - I (clause 2). Like the Huynh version, there are two other items in the Chin version that have reference 
to the title, but they are placed in the Rheme portion: me (clause 4) and my true red heart (clause 5).

As far as lexical choice is concerned, there are certain items in the translated versions which can be similar or equivalent to those in the source poem: the form white in the Balaban version, the Huynh version, and the Chin version can be equivalent to the form trắng in the source poem; the form round in the Balaban version, the Huynh version, and the Chin version can be equivalent to the form tròn in the source poem; the form rising in the Balaban version and bob in the Chin version to a certain extent can be equivalent to the form nổ in the source poem; the form sinking in the Balaban version and sink in the Huynh version and the Chin version to a large extent can be equivalent to the form chim in the source poem, and the reference of My body to The Floating Cake in the Balaban version, The Cake That Drifts In Water in the Huynh version, and Floating Sweet Dumpling in the Chin version to a certain extent can be considered to be comparable to the reference of Thân em to Bánh trôi nước in the source poem. There are, however, grammatical and lexical choices in the three translated versions which are very different from those in the source poem. As shown in our analysis in Section 3.3.1, the choices of my fate and Whatever way in the Balaban version, powdery, I, You, and You can't destroy in the Chin version, and The hand that kneads me in the Huynh and the Chin versions do not have correspondences in the source poem. It seems that the more delicate level we explore, the more differences or mismatches we can find between the translated versions and the source poem and between the translated versions.

One important factor that contributes to making the three versions of translation differ more markedly from the source poem is that there are some symbolic and cultural values attached to "Bánh trôi nước" having its origin in the Vietnamese culture (cf. Tran, 2012; Vuong, 2016) which do not seem to be laden in "The Floating Cake", "The Cake That Drifts In Water", and "Floating Sweet Dumpling". In reading "Bánh trôi nước", the reader is led into the realm of some metaphorical modes of meaning which, in this particular context, seem to be readily understood by the Vietnamese. For example, although the expression Thân em literally refers to the body of the Bánh trôi nước, it can be readily understood by the Vietnamese as a metaphor for the body of a woman; the expression Bảy nổi ba chìm với nước non is realized non-metaphorically by two material clauses Bảy nổi and ba chìm với nước non, it can be readily understood by the Vietnamese as a metaphorical expression indicating the vagabond now-up-and-now-down plight of the woman's life; and the expression tấm lòng son is realized non-metaphorically as a nominal group consisting of the noun tấm lòng (heart) functioning as Head/Thing and the adjective son (red) functioning as Epithet, it can be readily understood as a metaphorical expression indicating the faithfulness or loyalty of a woman. Seen from this point of view, it is doubtful whether Rising and sinking like mountains in streams in the Balaban version, In water I now swim, now sink in the Huynh version, and I sink and bob like a mountain in a pond in the Chin version are equivalent to Bảy nổi ba chìm với nước non in the source poem. It is even more doubtful whether my heart is red and true in the Balaban version, my true-red heart in the Huynh version, and my true red heart in the Chin version are equivalent to tấm lòng son in the source poem. 
5.2. Limitation of the study and suggestion for further research

As pointed out in Section 3.1, a text is an instance of language (Halliday, 1991; Halliday \& Hasan, 1976, 1985) which is a complex of several levels of meaning (Firth, 1957, 1968; Halliday \& Martin, 1993; Hasan, 2011). The implication of this statement is that the analysis for the meanings of a text should be done from as many levels as possible. In this paper, we have only been able to analyze and compare the three translated versions with the source poem mainly at clause level and have only mentioned in passing some of the metaphorical meanings that lie behind the source text which the target versions do not seem to possess. Further research, therefore, should be done to reveal the total meanings of the texts so that more similarities and differences between the source text and the translated versions, and between the translated texts themselves will be established.

It has been widely recognized (Hatim \& Mason, 1990; Bell, 1991; Venuti, 2008; Steiner, 1998; Levy, 2011) that poetic language is the most difficult to translate; and in most cases it is "untranslatable" (Jakobson, 2004: 118). This is because this kind of language usually contains in itself idiomatic expressions so unique to the experience of a culture that they cannot be fully translated into another language. Our examination and comparison of the three English versions of translation and the Vietnamese original poem "Bánh trôi nước" have demonstrated the challenges of poetic translation. The translators' dilemma in this particular context is that when translating they must capture their poems' phonological patterns (rhythm, rhyme, alliteration, assonance, etc.), morphological and syntactic patterns (words on the page and grammatical structures), semantic patterns (experiential, logical, interpersonal, and textual meanings), and poetics (imagery, metrics, etc.) as truthfully to the original as possible. Furthermore, they must go beyond those linguistic aspects to capture the cultural values that lie behind the source poem whose grammatical categories carry a high semantic import. These translation competences are "a tall order" (Vuong, 2016) which very few translators could possess. Our study has shown that different translators give different versions of the source poem. This raises the question of translatability in poetic translation, but unfortunately, we have not been able to discuss it in detail in our study, especially when the source poem sets high formal, semantic and cultural challenges to the translator. More research, therefore, should be conducted to explore the degrees of translatability from the source poem into the target poems in terms of these challenges.

\section{References}

\section{Vietnamese}

Diệp Quang Ban (2005). Ngũ pháp tiếng Việt (A Vietnamese Grammar). Hà Nội: Nxb. Giáo dục Việt Nam.

Halliday, M.A.K. (2012). Dẫn luận ngũ pháp chưc năng (An Introduction to Functional Grammar). In lần thứ ba. Hoàng Văn Vân dịch. Hà Nội: Nxb. Đại học Quốc gia Hà Nội.

Hoàng Phê et al. (2002). Tù điển tiếng Việt (A Vietnamese Dictionary). In lần thứ tám. Hà Nội: Nxb. Đà Nẵng.

Trần Nho Thìn (2012). Văn học Việt Nam tì̀ thế kỷ $X$ đến hết thế kỷ XIX (Vietnamese Literature from the Tenth Century to the End of the Nineteenth Century). Hà Nội: Nxb. Giáo dục Việt Nam.

Hoàng Văn Vân (2001a). Ngôn ngữ học chức năng hệ thống (Systemic Functional Linguistics). Ngôn $n g \tilde{u}$ (Journal of Language), 6(137), 12-19.

Hoàng Văn Vân (2001b). Ngôn ngữ học chức năng hệ thống (Systemic Functional Linguistics). Ngôn $n g \tilde{u}$ (Journal of Language), 9(140), 41-50. 
Hoàng Văn Vân (2005). Ngũ pháp kinh nghiệm của cú tiếng Việt: Mô tả theo quan điểm chức năng hệ thống (An Experiential of the Vietnamese Clause: A Systemic Functional Description). In lần thứ hai. Hà Nội: Nxb. Khoa học Xã hội.

Hoàng Văn Vân (2007). Về khái niệm Đề ngữ trong ngôn ngữ học chức năng (On the Notion of Theme in Functional Linguistics). Ngôn ngũ (Journal of Language), 2(213), 1-10.

Hoàng Văn Vân (2009). Về phạm trù chủ ngữ (On

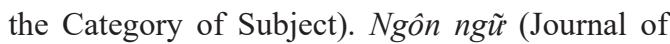
Language), 8(243), 1-13.

Hoàng Văn Vân (2013). Tính đa chức năng: Nguyên tắc tổ chức của ngôn ngữ (Multifunctionality: The Organizational Principle of Language). Ngôn ngũ (Journal of Language), 7(290), 14-34.

\section{English}

Bell, R.T. (1991). Translation and Translating: Theory and Practice. London \& New York: Longman.

Brown, G. \& G. Yule (1983). Discourse Analysis. Cambridge: Cambridge University Press.

Burns, M. (1990). Contexts of Competence: Social and Cultural Considerations in Communicative Language Teaching. New York \& London: Plenum Press.

Cook, G. (1989). Discourse. Oxford: Oxford University Press.

Crystal, D. (2008). A Dictionary of Linguistics and Phonetics. Sixth Edition. Singapore: Blackwell.

Eggins, S. (2004). An Introduction to Systemic Functional Linguistics. Second Edition. London: Continuum.

Firth, J.R. (1957). Papers in Linguistics 1934-1951. Oxford: Oxford University Press.

Firth, J.R. (1968). Selected Papers of J.R. Firth 195259. In Palmer, F.R. (Ed.). London: Longman.

Fries, P. H. (1981). On the Status of Theme in English: arguments from discourse. Forum Linguisitcum, 6(1), 1-38.

Gregory, M. \& S. Carroll (1978). Language Varieties and their Social Contexts. London, Henley and Boston: Routledge \& Kegan Paul.
Halliday, M.A.K. (1973). Explorations in the Functions of Language. London: Arnold.

Halliday, M.A.K. (1978). Language as Social Semiotic: The Social Interpretation of Language and Meaning. London: Edward Arnold.

Halliday, M.A.K. (1985). An Introduction to Functional Grammar. First Edition. London: Edward Arnold.

Halliday, M. A. K. (1991). The Notion of Context in Language Education. In Thao Le \& McCausland (Eds.), Language Education: Interaction and Development (pp. 1-25). Proceedings of the International Conference Held in Ho Chi Minh City, 30 March - 1 April, 1991. Launceston: University of Tasmania.

Halliday, M.A.K. (1992). Systemic Theory. In The Encyclopedia of Language and Linguistics. London: Pergamon Press.

Halliday, M.A.K. (1994). An Introduction to Functional Grammar. Second Edition. London: Edward Arnold.

Halliday, M.A.K. (1996). On Grammar and Grammatics. In Hasan, R., C. Cloran \& D. G. Butt (Eds.), Functional Description: Theory and Practice. Amsterdam: Benjamins.

Halliday, M.A.K. \& C.M.I.M. Matthiessen (1999). Construing Experience through Meaning: A Language-based Approach to Cognition. London \& New York: Cassell.

Halliday, M.A.K. \& R. Hasan (1976). Cohesion in English. Hong Kong: Longman.

Halliday, M.A.K. \& R. Hasan (1985). Language, Context, and Text: Aspects of Language in a Social-semiotic Perspective. Victoria: Deakin University Press.

Halliday, M. A. K. \& C. M. I. M. Matthiessen (2004). An Introduction to Functional Grammar. Third Edition. London: Edward Arnold.

Halliday, M.A.K. \& J.R. Martin (1993). Writing Science: Literacy and Discursive Power. London \& Washington D.C.: The Falmer Press.

Hasan, R. (1987). The Grammarian's Dream: Lexis as Most Delicate Grammar. In Halliday, M.A.K. \& R.P. Fawcett (Eds.), New Development in Systemic 
Linguistics. Volume I: Theory and Description. London \& New York: Frances Pinter.

Hasan, R. (1993). Context for Meaning. In Alatis, J.E. (Ed.), Georgetown University Round Table on Languages and Linguistics, 1992: Language, Communication and Social Meaning (pp. 79-103). Washington D.C.: Georgetown University Press.

Hasan, R. (2011). Selected Works of Ruqaiya Hasan on Applied Linguistics. Beijing: Foreign Language Teaching and Research Press.

Hasan, R. \& G. Perrett (1994). Learning to Function with the other Tongue: A Systemic Functional Perspective on Second Language Teaching. In Odlin, T. (Ed.), Perspectives on Pedagogical Grammar (pp. 179-226). Cambridge: Cambridge University Press.

Hatim, B. \& I. Mason (1990). Discourse and the Translator. London \& New York: Longman.

Hayakawa, S. I. (1959). Language in Thought and Action: How Men Use Words and Words Use Men. London: George Allen \& Unwin.

Hoang, V. V. (2005). The Meaning and Structure of a Science Fiction Story. VNU Journal of Science: Foreign Languages, 21(2), 28-45.

Hoang, V. V. (2006). Introducing Discourse Analysis. Hanoi: Vietnam Education Publishing House Co., Ltd.

Hoang V.V. (2012). An Experiential Grammar of the Vietnamese Clause. Hanoi: Vietnam Education Publishing House Co., Ltd.

http://www.chopsticksalley.com/singlepost/2016/10/03/A-Tale-of-Three-Translationsin-Poetry

Jabokson, R. (2004). On Linguistic Aspects of Translation. In Venuti, L. (Ed.), The Translation Studies Reader. London \& New York: Routledge. Pp. 113-18.

Levy, J. (2011). The Art of Translation. Translated by Patrick, C. Jettmarová, Z. (Ed.). Amsterdam/ Philadelphia: John Benjamins.

Martin, J.R. (1992). English Text: System and Structure. Amsterdam: John Benjamins.

Martin, J.R. \& D. Rose (2013). Working with
Discourse: Meaning Beyond the Clause. Second Edition. London \& New York: Bloomsbury.

Matthiessen, C.M.I.M. (1995) Lexicogrammatical Cartography: English Systems. Tokyo: International Language Sciences Publishers.

Matthiessen, C.M.I.M. \& J.A. Bateman (1991). Systemic Linguistics and Text Generation: Experience from Japanese and English. London: Frances Pinter.

Matthiessen, C.M.I.M., K. Teruya \& M. Lam (2010). Key Terms in Systemic Functional Linguistics. London: Continuum.

McCarthy, M. (2000). Discourse Analysis for Language Teachers. Cambridge: Cambridge University Press.

Nunan, D. (1993). Introducing Discourse Analysis. London: Penguin.

Schleppegrell, M.J. (2008). The Language of Schooling: A Functional Linguistics Perspective. Mahwah, New Jersey/London: Lawrence Erlbaum Associates, Publishers.

Steiner, G. (1998). After Babel: Aspects of Language and Translation. Third Edition. Oxford: Oxford University Press.

Thai, M.D. (2004). Metafunctional Profile of the Grammar of Vietnamese. In Caffarel, A., \& J. R. Martin (Eds.), Language Typology: A Functional Perspective. Amsterdam/Philadelphia, John Benjamins.

Thompson, G. (2004). Introducing Functional Grammar. Second Edition. London: Arnold.

Venuti, L. (2008). The Translator's Invisibility: A History of Translation. Second Edition. London \& New York: Routledge.

Vuong, V. (2016). A Tale of Three Translations in Vietnamese Poetry. Retrieved from http://www. chopsticksalley.com/single-post/2016/10/03/ATale-of-Three-Translations-in-Poetry.

Webster, J. (2015). Understanding Verbal Art: A Functional Linguistic Approach. London: Springer.

Wilss, W. (1982). The Science of Translation: Problems and Methods. Germany: Gunter Narr Verlag Tübingen. 


\title{
“BÁNH TRÔI NƯỚC”VÀ BA BẢN DICH TIẾNG ANH: SO SÁNH THEO LÍ THUYẾT CHỨC NĂNG HỆ THỐNG
}

\author{
Hoàng Văn Vân
}

Trung tâm Nghiên cưu Giáo dục Ngoại ngũu, Ngôn ngũ̃ và Quốc tế học,

Truờng Đại học Ngoại ngũu, ĐHQGHN, Phạm Văn Đồng, Cầu Giấy, Hà Nội, Việt Nam

Tóm tắt: Bài viết này so sánh ba bản dịch tiếng Anh: "The Floating Cake" của John Balaban, "The Cake That Drifts In Water" của Huỳnh Sanh Thông và "Floating Sweet Dumpling" của Marilyn Chin với bài thơ gốc tiếng Việt "Bánh trôi nước" của nữ thi sĩ lừng danh Hồ Xuân Hương. Khung lí thuyết sử dụng để phân tích và so sánh các văn bản là ngôn ngữ học chức năng hệ thống. Kết quả nghiên cứu cho thây có cả những điểm tương đồng và dị biệt giữa ba bản dịch với bài thơ gốc và giữa ba bản dịch với nhau trên ba bình diện nghĩa tư tưởng, nghĩa liên nhân và nghĩa ngôn bản. Kết quả nghiên cứu cũng chỉ ra rằng có nhiều điểm khác biệt ở cấp độ lựa chọn từ vựng (cấp độ lựa chọn từ và ngữ) hơn là ở cấp độ lựa chọn cấu trúc cú pháp (cấp độ lựa chọn các mẫu thức chuyển tác, thức và đề ngữ) giữa ba bản dịch và bài thơ gốc, và giữa ba bản dịch với nhau.

Từ khóa: ngôn ngữ chức năng hệ thống, ngôn cảnh, văn bản, siêu chức năng tư tưởng, siêu chức năng liên nhân, siêu chức năng ngôn bản, bài thơ gốc, các bản dịch 